\title{
THE JERICHO OASIS ARCHAEOLOGICAL PARK - 2015 INTERIM REPORT ITALIAN-PALESTINIAN COOPERATION FOR PROTECTION AND VALORIZATION OF ARCHAEOLOGICAL HERITAGE
}

\author{
Lorenzo Nigro - Gaia Ripepi - Sapienza University of Rome \\ Iyad Hamdan - Jehad Yasine -Ministry of Tourism and Antiquities of Palestine
}

In April 2015, the Italian Cooperation, Sapienza University of Rome and the Palestinian Ministry of Tourism and Antiquities started the Project "Oasis of Jericho" aimed at the implementation of the Jericho Oasis Archaeological Park (JOAP) by means of training of local personnel as tourist guides, specialized restorers and workers for the maintenance of 13 selected archaeological, historical, cultural, naturalistic, and religious sites in the Jericho Oasis, with the cooperation of the Ariha Municipality. Young students and workers participated in several activities, including sites rehabilitation and the production and installation of explanatory panels, the creation of visit itineraries and the involvement of the local community and stakeholders into the protection and valorization of the Jericho archaeological heritage.

Keywords: archaeology; cultural heritage; safeguard; management; valorization

\section{INTRODUCTION: THE JOAP PROJECT: AN EXAMPLE OF COOPERATION [LN-JY]}

The joint Italian-Palestinian Project "Jericho Oasis Archaeological Park" is the outcome of seventeen years (1997-2014) of fruitful cooperation in the field of archaeology between Sapienza University of Rome and the Palestinian Ministry of Tourism and Antiquities Department of Archaeology and Cultural Heritage (MOTA-DACH), which led to the complete scientific re-appraisal of Tell es-Sultan, and to a full rehabilitation of this mound, considered one of the most relevant archaeological sites of the ancient Near East. Such an enterprise was supported by the above mentioned Institutions and by the Italian Ministry of Foreign Affairs - Development Cooperation (MAECI).

The Project started from results achieved during the Pilot Project on Tell es-Sultan to further extend cooperation, rehabilitation and tourist valorization to other major archaeological sites in the Jericho Oasis and to contribute to sustainable development of the Oasis in the Municipality of Ariha with the support of the Italian Cooperation.

After the completion of the Jericho Master Plan by the Italian Cooperation, and as a consequence of previous joint work of MOTA-DACH and Sapienza, Tell es-Sultan was thus chosen for being the centre of the Jericho Oasis Archaeological Park (JOAP) including 13 archaeological, historical, cultural and natural sites, selected among the $105^{1}$ which are spread over the Oasis (fig. 1), and to host training sessions opened to young students and workers of the city of Ariha. With the support of the Italian Cooperation, the Project also involved the Municipality and local schools in order to let the local community to participate into the creation and management of the Park. The aim of the Project is to trigger economic and social development by means of sustainable tourism, distributed over a wide area and carried out by a variety of actors and stakeholders.

1 Nigro F. 2006, 193-195; Nigro - Sala - Taha eds. 2011, 95-99. 


\subsection{Setting: the Jericho Oasis - A human and natural outstanding heritage}

The Jericho Oasis, a unique ecosystem fed by three perennial sources of fresh water ('Ain es-Sultan, 'Ain Duq and 'Ain el-Auja) of extraordinary flow rate, witnessed some milestones in the history of Humankind - from the birth of agriculture, to the invention of mud-brick and pottery, to the rise of the city - which date back to the earliest Prehistory (Mesolithic and Pre-Pottery Neolithic), when the Jerichoan community gave birth to one of the largest fortified settlements of the Fertile Crescent. ${ }^{2}$ Even nowadays, archaeological remains which cover a time span of more than ten thousand years, are extraordinary preserved in a luxuriant natural scenario. ${ }^{3}$ This environment was heavily undermined in 1948 due to the installation of a refugee village right next to the archaeological site of Tell es-Sultan. Afterwards, both during the Israeli administration, and later within the rash development of the modern city of Ariha, after the birth of the Palestinian National Authority, modern building activities have severely threatened the environmental integrity of the Oasis and its cultural, anthropological and archaeological resources. For this reason, the joint efforts of Sapienza and MOTA focused on Tell es-Sultan, like those undertaken by the Italian Cooperation at Qasr Hisham and 'Ain es-Sultan, and more recently the realization of the city of Ariha Masterplan, ${ }^{4}$ represented a bulwark for the defence of the archaeological and cultural Heritage and the protection of the ecosystem of the Jericho Oasis. The same institutions have now resumed their commitment to safeguard such a patrimony which has been inscribed in position n. 2, after Bethlehem - Birthplace of Jesus in UNESCO's World Heritage Sites List. ${ }^{5}$

\subsection{Archaeological heritage valorization and sustainable tourism development}

Protection of antiquities and safeguard of monuments and natural resources - including landscape - not only is a duty, but is also an opportunity to exploit through proper valorization an almost unique environment. In this perspective, the JOAP is seen as a tool to support a sustainable development within the Ariha Municipality, based on cultural tourism. The Park, with its spatially distributed organization and monumental variety, is a strategic asset to activate niche and quality tourism for the benefit of the local community. Tell es-Sultan, with its more than 300,000 annual visitors, is yet a major tourist resource in Palestine and, being the JOAP centre, it will trigger the development of a densely interconnected territorial tourist network. With the other 13 rehabilitated sites, it can definitely enhance specialised tourism, promoting a positive spiral that qualifies, differentiates and increases tourism, providing employment opportunities and improving the outreach of a successful field research.

\footnotetext{
A comprehensive summary of the history of Jericho is offered in Nigro 2013.

Taha - Qleibo 2010.

Ceccarelli - Occhialini eds. 2014.

Taha 2012
} 


\subsection{High qualified and trained personnel as a clue for tourism flourish}

The overall aim of the project is the enhancement of the Park as a tool for economic and cultural development to the advantage of the whole community of Ariha. It is pursued by training of specialized personnel of the MOTA-DACH and the Municipality, and through the job placement of young people (mainly Palestinian students from Bir-Zeit and Al-Quds Universities) to be transformed into high qualified archaeological guides and natural experts of the Oasis, as well as into skilled restorers and workers for the Park maintenance. Beneficiaries of the project are executives and employees of the MOTA-DACH, employees of the Municipality and young students, in addition to the community of Ariha and consumers of tourism in Jericho arriving from everywhere.

\subsection{Synergy as strategy involving young local students}

The Project is hinged on the creation of a Tourist Information Centre (TIC), which, thanks to the trained personnel (archaeologists, tourist managers, specialized workers for sites-maintenance, tourist guides) from different institutions (MOTA, Municipality, Universities), can launch tours along selected itineraries for groups, schools or individual cultural tourists. The project programme ensures a progressive involvement of such students/participants into the management of the Park and its tourist valorization.

\subsection{Articulation and timing}

The Project was organized to achieve the goals in consequential, interrelated and progressive path, subdivided into clearly defined activities with two milestones in two years. During this period, nine training activities will be carried out: a first class (A1) for capacity building and the creation of itineraries for archaeologists and tour operators; and a second class (A2) for the implementation of these paths at various sites and the concomitant formation of the tourist guides. Two trainings on the job (B1, B2) to educate specialized workers in monuments restoration and maintenance, and archaeologists and tour operators for the evaluation of the state of preservation of sites. These first steps of the Project, accomplished during the first year (2015), are accounted in the present report.

After the set-up of the TIC (C), in the second year, the first cycle of the Training Course of Park operators (D), followed by the first class of management (F1) take place. Two employees of the MOTA-DACH will be then hosted in Rome as students of Post Graduate classes in Archaeology and Cultural Heritage (E). A second cycle of training activities based in the TIC and involving schools (F2) will provide a further qualification for the staff of the MOTA, with a recognized degree of local tourist guides. The opening conference of the Park (G) and a final class of three months, in which the students will gradually start the everyday activities of tours, visits and other services of the JOAP, will complete the project. 
During all stages, the Project is under the direct control of the Italian Cooperation (in Rome and Jerusalem), which monitors and constantly realigns it towards the established goals. ${ }^{6}$

\section{THE THIRTEEN SITES OF THE JOAP [GR-IH]}

Thirteen sites were preliminary chosen because of their historical and cultural importance to be part the JOAP (fig. 2). They have been refurbished and provided with convenient explanatory devices and paths for tourist appraisal. This directly contributed to their safeguard and preservation. The sites were put on the map and fenced and were connected by the three main visit itineraries (archaeological, naturalistic and religious; $\S$ 5.). Site n.1 is Tell es-Sultan, which was also chosen to be the JOAP centre. The selected sites included:

1. Tell es-Sultan ${ }^{7}-$ Ancient Jericho

2. Tell el-Mafjar ${ }^{8}$ - Chalcolithic Settlement

3. Tulul Abu el-'Alayiq ${ }^{9}$ - King Herod's Palace

4. Tell es-Samarat ${ }^{10}$ - Herod's Hippodrome

5. Tawaheen es-Sukkar ${ }^{11}$ - Mameluk Sugar Mills

6. Tell el-Matlab ${ }^{12}$ - Roman-Byzantine site

7. Tell el-Hasan ${ }^{13}$ - Byzantine church

8. Tell el-Qos ${ }^{14}$ - Byzantine Jericho

9. Tell Abu Hindi ${ }^{15}$ - Byzantine churches

10. Khirbet el-Mafjar ${ }^{16}$ - Caliph Hisham's Palace

11. Aqueduct and pool of Khirbet el-Mafjar

12. 'Ain es-Sultan ${ }^{17}-$ Spring and water devices

13. Jebel Quruntul ${ }^{18}$ - Mount of Temptation (monastery and landscape).

6 The Authors wish to deeply thank, for their constant overlooking and support, the Italian General Consul in Jerusalem, H.E. Davide La Cecilia, the Vice-Consul, H.E. Elena Clemente, the head of the Italian Cooperation in Jerusalem Dr. Vincenzo Racalbuto, the Project responsible in Rome, Dr. Emanuela Benini.

7 Sellin - Watzinger 1913; Kenyon 1981; 1993; Marchetti - Nigro eds. 1998; 2000; Nigro 2006; 2013; Nigro Taha eds. 2006; Nigro - Sala - Taha eds. 2011.

8 Mellaart 1962; Taha et al. 2004; Anfinset 2006.

9 Netzer 1993a; 2001a; 2001b; 2006.

10 Augustinović 1951, 177-178; Mellaart 1962, 156, n. 87; Netzer 1993b.

11 Augustinović 1951, 118-120; Taha 2001; 2009.

12 Clermont-Ganneau 1896, 17-20; Conder - Kitchener 1883, 222; Augustinović 1951, 145-151.

13 Augustinović 1951, 83-84; Baramki 1955; Foerster 1993; Cirelli - Zagari 2000, 366.

14 Conder - Kitchener 1883, 222; Augustinović 1951, 266; Cirelli - Zagari 2000, 366.

15 Conder - Kitchener 1883, 221; Augustinović 1951, 50, 55, 66; Ovadiah 1970, 72-73; Cirelli - Zagari 2000, 366.

16 Whitcomb 1988; Hamilton 1993; Whitcomb - Taha 2013; Taha - Whitcomb 2014.

17 Dorrell 1993.

18 Clermont-Ganneau 1896, 20-21; Conder - Kitchener 1883, 201-204; Augustinović 1951, 130-138, figs. 43-45; Cirelli - Zagari 2000, 366, 369; Zagari 2000, 357. 


\section{ACTIVITY A: ARCHAEOLOGICAL SITES REFURBISHING AND PRESENTATION [GR]}

Activity A was subdivided into two different actions: Activity A1, capacity building for archaeological sites location, mapping, surveying and enhancement; Activity A2, capacity building for selected sites valorization and interconnection by means of the creation of thematic tourist paths of the Jericho Oasis Archaeological Park. Both activities were carried out simultaneously with the main aim to train young students as tour guides, taking into account the social and environmental context of Jericho. As a useful tool for the Project, a web site (www.lasapienzatojericho.it/JOAP) and a Facebook page were created hosting all contents and information concerning the JOAP and its ongoing activities.

\subsection{Activity A1: sites delimitation and refurbishing}

The first phase of training of local students, MOTA and Ariha Municipality personnel, was oriented to a direct contact with selected sites and their surroundings. Students participated into a series of visits to JOAP sites being instructed how to evaluate archaeological potential and state of preservation of each monument. They were taught about how to identify possible presence of territorial and environmental threats, how to cope with them, and how to highlight resources to be valorized in each site (figs. 3-4). ${ }^{19}$ This activity also allowed to experiment on the ground paths and to locate more precisely each site. Moreover, students were trained in basic archaeological techniques of surveying and materials processing. During surveys on the sites, objects and ceramic materials were collected useful to illustrate their material culture and methods of documentation, classification, and management of archeological data (fig. 5).

During the second educational phase of Activity A1, information was given about history, archaeological remains, naturalistic, cultural and religious significance of each site of the Park. The information was then used by the same students to realize explanatory panels to be set in each site, including observations and data obtained during surveys. ${ }^{20}$ Students also acquired computer skills necessary for the realization of panels and directly participated in contents and graphics composition of the latter, as well as in the translation of English texts into Arabic ones (figs. 6-7). The panels were then produced by a specialized company in Ramallah, together with sticks and other material useful to facilitate the awareness of local population about the JOAP and the IT-COOP and MOTA-DACH joint project.

A non-secondary aspect of Activity A was the cleaning and arrangement of sites, which has been carried out in cooperation with the Ariha Municipality (figs. 8-9). All sites were refurbished, sweeping off garbage and dumps, fencing them, making paths and view points, and selecting the right spots where to install the explanatory panels (fig. 10). This works were realized with the direct participation of students, who also personally contributed to the implementation of paths and to their practical realization.

19 Nigro - Sala - Taha eds. 2011, 95-99.

20 A special contribution to this session of the Project was given by Dr Mohammed Jaradat of the MOTADACH. 


\subsection{Activity A2: creation and implementation of visit itineraries}

How to let public enjoy the JOAP and its archaeological, historical, religious and naturalistic highlights? This question was raised in order to develop itineraries to be proposed to visitors interested in different aspect of Jericho and its cultural heritage, with different time availability.

Activity A2 was, thus, devoted to the creation and implementation of such itineraries. Students and over viewers identified three main thematic routes connecting ancient sites and panoramic places: the Archaeological Itinerary, the Naturalistic Itinerary, and the Religious Itinerary (www.lasapienzatojericho.it/JOAP/Itineraries.php).

The Archaeological Itinerary was sub-divided into three possible thematic routes respectively entitled:

- "The Jericho Oasis in history" (fig. 11), including the sites of Tell es-Sultan, Tell el-Mafjar, Tulul Abu el-'Alayiq, Tell es-Samarat, Tawaheen es-Sukar, Tell elHasan, Tell Abu Hindi and Khirbet el-Mafjar, offering a complete picture of the archaeology of the Oasis through the most important steps of the history of Humakind as witnessed in Jericho (7 hours);

- "Short visit to the main sites of JOAP" restricted to Tell es-Sultan, Tell Abu el'Alayiq, Khirbet el-Mafjar and Jebel Quruntul (the Mount of Temptations) providing a fully satisfactory tourist overview of the Oasis (4 hours);

- "Jericho city of power" including Tell es-Sultan and Tulul Abu el-'Alayiq, that it is to say the two sites were the palaces of the Lords of the Bronze and Iron Age city and the Hasmonean Kings were uncovered (3 hours).

The Naturalistic Itinerary consists of one traditional path entitled "Jericho's water resources"; and two trekking routes, respectively named "Nature and spirituality" and "Discovering Bedouin lifestyle in Wadi Qelt". The three naturalistic/trekking itineraries were thus:

- “Jericho’s water resources” (fig. 12) is a walk into the flourishing nature of Jericho to discover the primary resource of the Oasis, water ('Ain es-Sultan; 'Ain el-Auja; 'Ain Duq; Aqueduct and pool of Khirbet el-Mafjar). Wild flora and fauna, survived along the banks of wadiat, as well as peasants and shepherds way of life preserved through centuries, can be experimented on this path (31/2 hours).

- "Nature and spirituality", a trekking route which includes the sites of 'Ain el-Auja and Jebel Quruntul. It foresees an ascent to the monastery through the mountain path which offers a wonderful panorama over the whole Oasis (4 hours).

- "Discovering Bedouin lifestyle in Wadi Qelt” is a trekking walk along Wadi Qelt with the canals driving water to the Oasis and a beautiful sight over the Jordan Valley and the Dead Sea, including a stop by a Bedouin tent for dining, drinking Arabic coffee, and wearing real Bedouin clothes (3 hours).

Finally, the Religious Itinerary was entitled "The walk of pilgrims" (fig. 13). It foresees the visit to the following sites: Sycamore Tree and the Russian Orthodox Museum, Jebel Quruntul (Mount of Temptations and Monastery of Saint George), the Fountain of Prophet Elisha ('Ain es-Sultan) and the Synagogue of Na'aran (4 hours). 


\section{ACTIVITY B: TRAINING OF SPECIALIZED WORKERS FOR RESTORATION AND MAINTENANCE OF JOAP MONUMENTS [GR]}

This Activity pointed to the preservation of mudbrick architecture as a distinguished tradition of the Jericho Oasis. ${ }^{21}$ Training of workers in maintenance and rehabilitation of monuments aimed at the creation of a group of local specialists who could be employed in several sites within the Park. To achieve this goal, two major actions were carried out on two selected monuments of Tell es-Sultan: Tower A1 and Palace G. Training was focused on techniques of protection and restoration of mud-brick structures, as well as on their surface protection by means of traditional straw and mud plaster.

\subsection{Activity B1: training on the job - restoration of Tower A1}

The first action (Activity B1) was carried out on Tower A1, a rectangular structure of the Middle Bronze I-II (1900-1650 BC), ${ }^{22}$ built entirely of mud bricks, on a stone foundation, the conservation status of which was particularly exposed to risks (fig. 14) and could exemplify a series of recurrent technical challenges in restoration.

Before starting the activity, workers were recruited from the weaker strata of the local farmers population (which still are accustomed to earthen architecture) in order to contribute to social growth. During the first weeks the workers were trained in the production of mud bricks (fig. 15). Initial instructions regarded the amount and proportions of raw materials for a good mixture, ${ }^{23}$ the time and the way for drying and storing. Secondly, the making of bricks required for the restoration of Tower A1 started using wooden molds with standard dimensions $(52 \times 36 \times 15 \mathrm{~cm})$.

When the new bricks were ready, workers were trained in cleaning the existing mudbrick monument, removing already compromised material and preparing the mortar bed for the layer of new protective bricks (fig. 16). They were, then, laid on the tower under the guidance of a professional restorer (an Italian and a Palestinian one, in order to develop also technical language and communication). Bricks arrays were arranged according to the original displacement, which followed meticulous rules of statics, reinforcing the structure at walls junctions (fig. 17). Bricks were placed as headers, staggering the bricks of the top row, to avoid a continuous vertical joint. At the junction points between perpendicular walls, bricks were cut into halves and were positioned in between the two walls, creating a stronger bond. In some endangered spots, bricks were replaced to strengthen the overall consistency of the monument.

One of the most interesting aspects of this phase of training, was that, among workers, there were some in possession of technical knowledge on mud bricks architecture, which is still used in the Oasis of Jericho (the enhancement of which as a cultural heritage, is one of the overall aims of the Project). The exchange of information and expertise about methods of construction of mud bricks architecture was thus a fruitful outcome of the activity, contributing to the transmission of a local tradition.

1 Ripepi 2014.

22 Nigro - Taha 2009, 731-734; Nigro - Sala - Taha - Yasine 2011, 573-577.

23 Cerulli 2000, 351. 
The restoration, as jointly established with the MOTA-DACH, continued by coating the structure with traditional plaster and the realization of a sacrifice revetment around the basis of the structure (fig. 18), to ensure a proper insulation from humidity and to contrast erosion. ${ }^{24}$

In order to facilitate the reading of monuments after their restoration, new tourist paths were arranged all around their areas, and a series of signals giving the name and dating of each structure were set up (fig. 19).

\subsection{Activity B2: training on the job - restoration of Palace G and Building B1}

The second action (Activity B2) was carried out on Palace G of the Early Bronze III (2700-2300 BC), located in the central area of the site, known as Spring Hill. ${ }^{25}$ The building covers an area of about 500 square meters and extended on three different terraces, placed at different elevations (fig. 20). In this case, it was necessary a larger scale assessment, which took into account the morphological conditions and the size of the structure. The first step was to teach production of bricks, of a different size in respect of those of Tower A1, measuring $42 \times 21 \times 15 \mathrm{~cm}$. The laying of bricks in sacrifice layers and repairs again followed a precise pattern descending from that used in the original building, staggering in each row, to avoid a continuous vertical joint and alternating them as headers and stretchers to make stronger the static bonds (fig. 21). To solve the problems of erosion, water drainage channels (fig. 22) both along the perimeter of the structure and inside some of the main walls, were set ${ }^{26}$. All the walls of the palace were restored and, successively, were coated with traditional plaster for surfaces protection (fig. 23).

In Activity B2 workers already trained in B1 could experiment the techniques they learned on a larger and more complex scale. Moreover, at the end of the workshop, the whole area surrounding Palace $G$ was rehabilitated in order to let visitors profit of the panorama and be able to understand the monument in a convenient way (fig. 24). A major drainage channel preventing the Spring Hill from rainwater erosion, lined with stones, was also built. The view point for groups under the shelter on Spring Hill summit, located some meters north of Palace G, was refurbished and panels in Arabic and English were set up illustrating the monument and the archaeological finds inside it, as well as their historical setting and significance.

Finally, a small scale intervention was carried on Building B1, ${ }^{27}$ a subsidiary edifice connected with the fortification of the Early Bronze III (2450-2300 BC) city. There, walls were particularly damaged by water infiltration. After cleaning, broken bricks were removed and replaced with new ones, according to the original laying scheme. Mud bricks with typical Early Bronze III dimensions $(42 \times 21 \times 13 \mathrm{~cm})$ were replaced setting them alternately as headers and stretchers. All the walls of Building B1 were re-plastered with traditional mud and straw plaster in order to protect the structures from atmospheric agents and to make the reading of its architecture easier (fig. 25).

24 Diab 2006, 234-235.

25 Nigro - Sala - Taha - Yasine 2011, 585-592.

26 Nigro F. 1998, 218-219; 2000, 289.

27 Nigro - Panciroli - Ghayyada 2000, 135-138. 
Through Activity B, thirteen workers were formed in the techniques of mud brick restoration and rehabilitation of ancient Pre-Classical monuments, experimenting different methods from the making of bricks to their laying into walls and plastering. Moreover, students participating into the Project were also involved in archaeological areas refurbishing with creation and setting of new tourist paths and explanatory panels. ${ }^{28}$

\section{RESULTS AND PERSPECTIVES}

Activities A and B were carried out between April and November 2015, rehabilitating 13 sites including Tell es-Sultan, and opening them to the visit of tourist individuals and groups. In the meantime, the Ariha Municipality Info Point started to provide information also on the Jericho Oasis Archaeological Park (with an employee trained with the students participating into Activity A), with the help of the online web site of the Project (www.lasapienzatojericho.it/JOAP). Local tourist agencies (http://www.rozana.ps/) were also involved to promote experiential and rural tourism in the Oasis.

During Activity A fifteen students (fig. 26) were trained in archaeological techniques and as sites contents developers and illustrators (tourist guides for schools and producers of explanatory panels). Sites were put on a map, surveyed, fenced. Thirteen explanatory panels were set up one in each site of the Park, including English and Arabic texts illustrating the sites and their monuments (fig. 27).

Activity B allowed to train thirteen workers specialised in archaeological sites cleaning, maintenance, and restoration of mud brick architecture (fig. 28). Three monuments were restored at Tell es-Sultan and all of the sites of the Park were cleaned and rehabilitated also arranging view points and paths for tourists.

Finally, Tourist Itineraries were organized across the Park, according to three main tracks (Archaeological Itinerary, Naturalistic Itinerary, and Religious Itinerary) illustrated in the online web site, with maps and indications letting the visitor to be aware of archaeological, historical, cultural, naturalistic and religious contents of different sites and the time necessary to visit and appraise them.

28 Detailed step by step information on Activity $\mathrm{B}$ is available in the Project web site: www.lasapienzatojericho.it/JOAP. 


\section{REFERENCES}

ANFINSET, N.

2006 The Joint Palestinian-Norwegian Expedition at Tell el-Mafjar: L. NigRO - H. TAHA (eds.), Tell es-Sultan/Jericho in the Context of the Jordan Valley: Site Management, Conservation and Sustainable Development. Proceedings of the International Workshop Held in Ariha $7^{\text {th }}-11^{\text {th }}$ February 2005 by the Palestinian Department of Antiquities and Cultural Heritage - Ministry of Tourism and Antiquities, UNESCO Office - Ramallah, Rome "La Sapienza” University (Rome «La Sapienza» Studies on the Archaeology of Palestine \& Transjordan 2), Rome 2006, pp. 63-82.

Augustinović, A.

1951 Gerico e dintorni, Jerusalem 1951.

BARAMKI, D.C.

1955 The Excavations at Khirbet en-Nitla: J.L. KeLso - D.C. BARAmKI, Excavations at New Testament Jericho and Khirbet en-Nitla (Annual of the American Schools of Oriental Research 29-30, 1949-1951), New Haven 1955, pp. 50-52.

CeCCARELli, P. - OcChialini, E. (eds.)

$2014 \quad$ Jericho Masterplan. A model for sustainable development, Bethlehem 2014.

CERULLI, T.

2000 Analysis of mudbrick samples from tell es-Sultan (Jericho): N. MARCHETTI - L. NiGRO (eds.), Excavations at Jericho, 1998. Preliminary Report on the second season of Excavations and Surveys at Tell es-Sultan, Palestine (Quaderni di Gerico 2), Rome 2000, pp. 349-354.

Cirelli, E. - ZAGARI, F.

2000 L'oasi di Gerico in età bizantina e islamica. Problemi e proposte di ricerca: Archeologia Medievale 27 (2000), pp. 365-376.

CLERMONT-GANNEAU, C.

1896 Archaeological Research in Palestine During the Years 1873-1874, Vol. II, London 1896. CONDER, C.R. - KITCHENER, H.H.

1883 The Survey of Western Palestine: Memoirs of the Topography, Orography, Hydrography, and Archaeology. Volume III. Sheets XVII-XXVI. Judaea, London 1883.

DIAB, $\mathrm{M}$

2006 Conservation of Mud-Brick Structures at Tell es-Sultan: L. NigRo - H. TAHA (eds.), Tell es-Sultan/Jericho in the Context of the Jordan Valley: Site Management, Conservation and Sustainable Development. Proceedings of the International Workshop Held in Ariha 7th - 11th February 2005 by the Palestinian Department of Antiquities and Cultural Heritage - Ministry of Tourism and Antiquities, UNESCO Office - Ramallah, Rome "La Sapienza" University (Rome «La Sapienza» Studies on the Archaeology of Palestine \& Transjordan 2), Rome 2006, pp. 227-236.

DORRELL, P.

1993 The Spring of Jericho from early photographs: Palestine Exploration Quarterly 125 (1993), pp. 95-114.

FOERSTER, G.

1993 Tell el-Hassan: E. STERN (ed.), The New Encyclopedia of Excavations in the Holy Land, Vol. 2, Jerusalem 1993, pp. 696-697.

HAMILTON, R.W.

1993 Khirbet el-Mafjar: E. STERn (ed.), The New Encyclopedia of Excavations in the Holy Land, Vol. 2, Jerusalem 1993, pp. 922-929. 
KENYON, K.

1981 Excavations at Jericho volume III. The Architecture and Stratigraphy of the Tell, London 1981.

1993 Jericho: E. STERn (ed.), The New Encyclopedia of Archaeological Excavations in the Holy Land, Vol. 2, Jerusalem 1993, pp. 674-681.

MARChETTI, N. - NigRo, L. (eds.)

1998 Scavi a Gerico, 1997. Relazione preliminare sulla prima campagna di scavi e prospezioni archeologiche a Tell es-Sultan, Palestina (Quaderni di Gerico 1), Roma 1998.

2000 Excavations at Jericho, 1998. Preliminary Report on the Second Season of Excavations and Surveys at Tell es-Sultan, Palestine (Quaderni di Gerico 2), Rome 2000.

MELLAART, J.

1962 Preliminary Report on the Archaeological Survey in the Yarmouk and Jordan Valleys: Annual of the Department of Antiquities of Jordan 6-7 (1962), pp. 126-157.

NETZER, E.

1993a Tulul Abu el-'Alayiq: E. STERn (ed.), The New Encyclopedia of Archaeological Excavations in the Holy Land, Vol. 2, Jerusalem 1993, pp. 682-691.

1993b Tell es-Samarat: E. STERN (ed.), The New Encyclopedia of Archaeological Excavations in the Holy Land, Vol. 2, Jerusalem 1993, pp. 691-692.

2001a Hasmonean and Herodian Palaces at Jericho: Final Reports of the 1973-1987 Excavations. Volume I: Stratigraphy and Architecture, Jerusalem 2001.

2001b Palaces of the Hasmoneans and Herod The Great (Studies in Biblical History and Archaeology), Jerusalem 2001.

2006 The Architecture of Herod the Great Builder (Texts and Studies in ancient Judaism 117), Tübingen 2006.

NigRo, F.

1998 Il parco archeologico per la conservazione e la valorizzazione di Tell es-Sultan, antica Gerico: N. MarchetTi - L. Nigro (eds.), Scavi a Gerico, 1997. Relazione preliminare sulla prima campagna di scavi e prospezioni archeologiche a Tell es-Sultan, Palestina (Quaderni di Gerico 1), Roma 1998, pp. 205-229.

2000 The 1998 season at Tell es-Sultan: measures for protection and development of the site. A project for ancient Jericho: N. MARCHETTI - L. NIGRO (eds.), Excavations at Jericho, 1998. Preliminary Report on the Second Season of Excavations and Surveys at Tell es-Sultan, Palestine (Quaderni di Gerico 2), Rome 2000, pp. 287-296.

2006 Cultural Heritage Planning and Management for Development: the Palestinian Archaeological Park of the Jericho Oasis: L. Nigro - H. TAHA (eds.), Tell esSultan/Jericho in the Context of the Jordan Valley: Site Management, Conservation and Sustainable Development. Proceedings of the International Workshop Held in Ariha 7th 11th February 2005 by the Palestinian Department of Antiquities and Cultural Heritage Ministry of Tourism and Antiquities, UNESCO Office - Ramallah, Rome "La Sapienza" University (Rome «La Sapienza» Studies on the Archaeology of Palestine \& Transjordan 2), Rome 2006, pp. 191-208.

NigRO, L.

2006 Preserving the History and Archaeology of Palestine at Tell es-Sultan: the Contribution of Rome "La Sapienza" University: L. NIGRO - H. TAHA (eds.), Tell es-Sultan/Jericho in the Context of the Jordan Valley: Site Management, Conservation and Sustainable Development. Proceedings of the International Workshop Held in Ariha 7th - 11th February 2005 by the Palestinian Department of Antiquities and Cultural Heritage Ministry of Tourism and Antiquities, UNESCO Office - Ramallah, Rome "La Sapienza" 
University (Rome «La Sapienza» Studies on the Archaeology of Palestine \& Transjordan 2), Rome 2006, pp. 95-110.

2013 Jericho: D.M. MASTER (ed.), The Oxford Encyclopedia of the Bible and Archaeology vol. 2, Oxford 2013, pp. 1-9.

Nigro, L. - SALA, M. - TAHA, H. (eds.)

2011 Archaeological Heritage in the Jericho Oasis. A systematic catalogue of archaeological sites for the sake of their protection and cultural valorization (Rome «La Sapienza» Studies on the Archaeology of Palestine \& Transjordan 7), Rome 2011.

Nigro, L. - SALA, M. - TAHA, H. - YASINE, J.

2011 The Early Bronze Age Palace and Fortifications at Tell es-Sultan/Jericho. The 6th - 7th seasons (2010-2011) by Rome "La Sapienza" University and the Palestinian MOTADACH: Scienze dell'Antichità 17 (2011), pp. 571-597.

NigRo, L. - TAHA, H.

2009 Renewed Excavations and Restorations at Tell es-Sultan/Ancient Jericho. Fifth Season March-April 2009: Scienze dell’Antichità 15 (2009), pp. 731-744.

NigRO, L. - TAHA, H. (eds.)

2006 Tell es-Sultan/Jericho in the Context of the Jordan Valley: Site Management, Conservation and Sustainable Development. Proceedings of the International Workshop Held in Ariha 7th - 11th February 2005 by the Palestinian Department of Antiquities and Cultural Heritage - Ministry of Tourism and Antiquities, UNESCO Office - Ramallah, Rome "La Sapienza" University (Rome «La Sapienza» Studies on the Archaeology of Palestine \& Transjordan 2), Rome 2006.

Nigro, L. - PANCiRoli, B. - GHAYYADA, M.

2000 Architecture and stratigraphy of Building B1: N. MARChETti - L. Nigro (eds.), Excavations at Jericho, 1998. Preliminary Report on the Second Season of Excavations and Surveys at Tell es-Sultan, Palestine (Quaderni di Gerico 2), Rome 2000, pp. 121-163.

OVADIAH, A

1970 Corpus of Byzantine Churches in the Holy Land (Theophaneia. Beiträge zur religionsund Kirchengeschichte des Altertums 22), Bonn 1970.

RIPEPI, G.

2014 L'architettura in mattoni crudi a Tell es-Sultan/Gerico dal Neolitico all'età del Bronzo Medio, PhD Diss. Sapienza University, Rome 2014.

SELLIN, E. - WATZINGER, C.

1913 Jericho. Die Ergebnisse der Ausgrabungen (Wissenschaftliche Veröffentlichung der Deutschen Orient-Gesellschaft 22), Leipzig 1913.

TAHA, $\mathrm{H}$.

2001 The Excavation of Tawaheen es-Sukkar in the Jordan Valley: Orient Express 2001/3, pp. 68-71.

2009 Some aspects of sugar production in Jericho, Jordan Valley: E. KAPTJIN - L.P. PETIT (eds.), A Timeless Vale: Archaeological and related Essays on the Jordan Valley in Honour of Gerrit van de Kooij on the occasion of his sixty-fifth birthday (Archaeological Studies Leiden University 19), Leiden 2009, pp. 181-191.

2012 The Story of Inscribing Bethlehem on the World Heritage List: This Week in Palestine 172 (2012), pp. 6-12.

TAHA, H. - QLEIBO, A.

$2010 \quad$ Jericho, a living history. Ten thousand years of civilization, Jerusalem 2010.

TAHA, H. - WHITCOMB, D.

2014 The Mosaics of Khirbet el-Mafjar Hisham’s Palace, Ramallah 2014. 
TAHA, H. - ANFinset, N. - YAsine, J. - ZAWAhira, M.

2004 Preliminary report on the first season of the Palestinian-Norwegian excavation at Tell elMafjer, Jericho: Orient Express 2004/2, pp. 40-44.

WHITCOMB, D.

1988 Khirbet el-Mafjar Reconsidered: the Ceramic Evidence: Bulletin of the American Schools of Oriental Research 271 (1988), pp. 51-67.

WHITCOMB, D. - TAHA, $\mathrm{H}$.

2013 Khirbet al-Mafjar and its place in the Archaeological Heritage of Palestine: Journal of ZAGARI, F. eastern Mediterranean archaeology and heritage studies 1/1 (2013), pp. 54-65.

2000 Appendix H: Remarks on the Byzantine occupation of Tell es-Sultan: N. MARCHETTI - L. NigRo (eds.), Excavations at Jericho, 1998. Preliminary Report on the Second Season of Archaeological Excavations and Surveys at Tell es-Sultan, Palestine (Quaderni di Gerico 2), Rome 2000, pp. 355-381. 


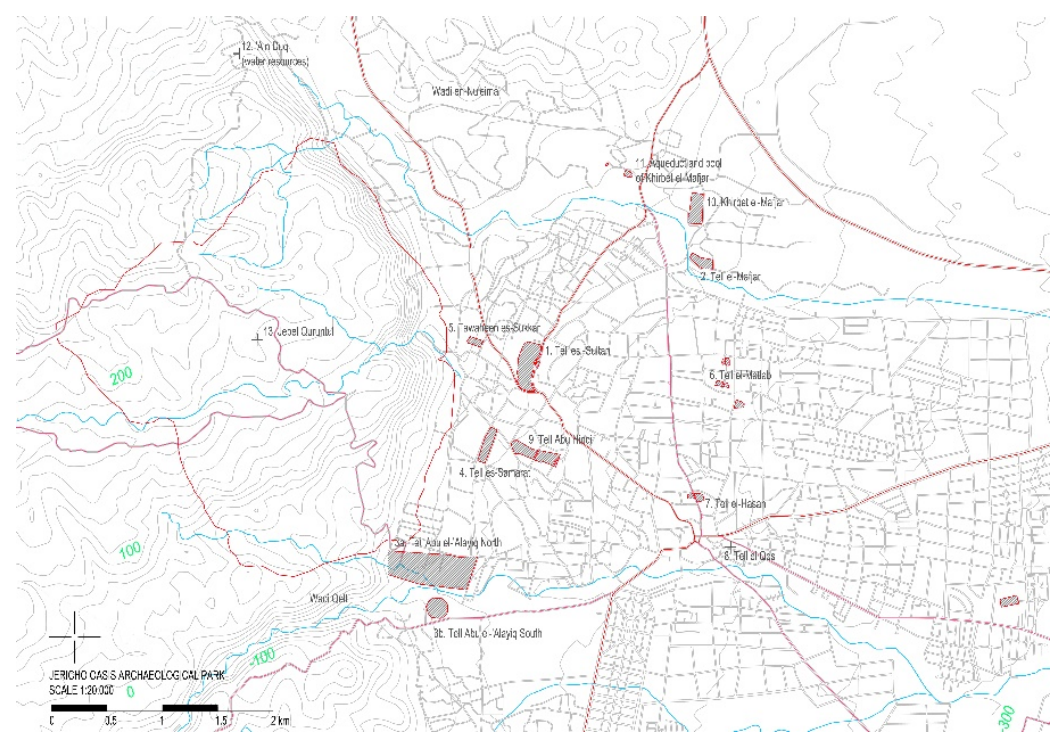

Fig. 1 - Topographic map of the Jericho Oasis with the JOAP sites.

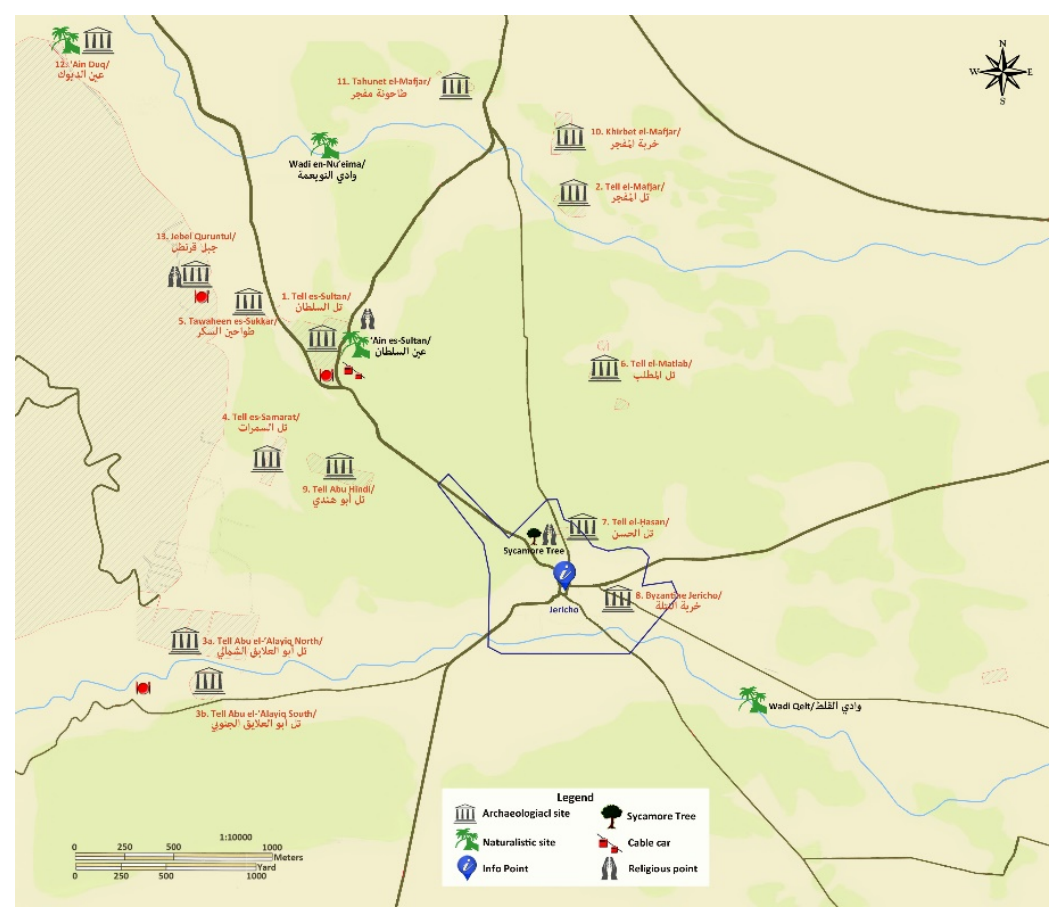

Fig. 2 - Tourist map of the Jericho Oasis with the archaeological, naturalistic and religious sites of the JOAP. 


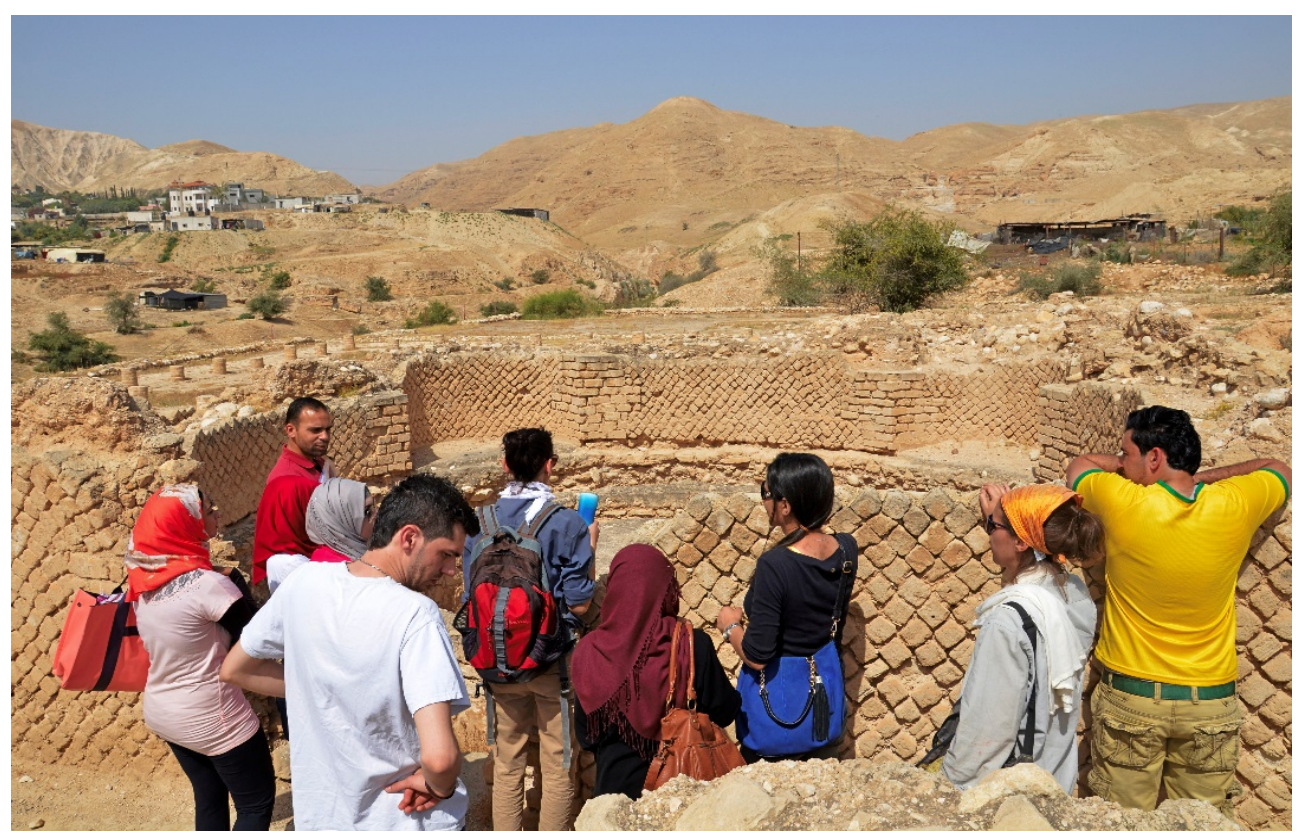

Fig. 3 - Students of the JOAP Guides School visiting Tulul Abu el-‘Alayiq.

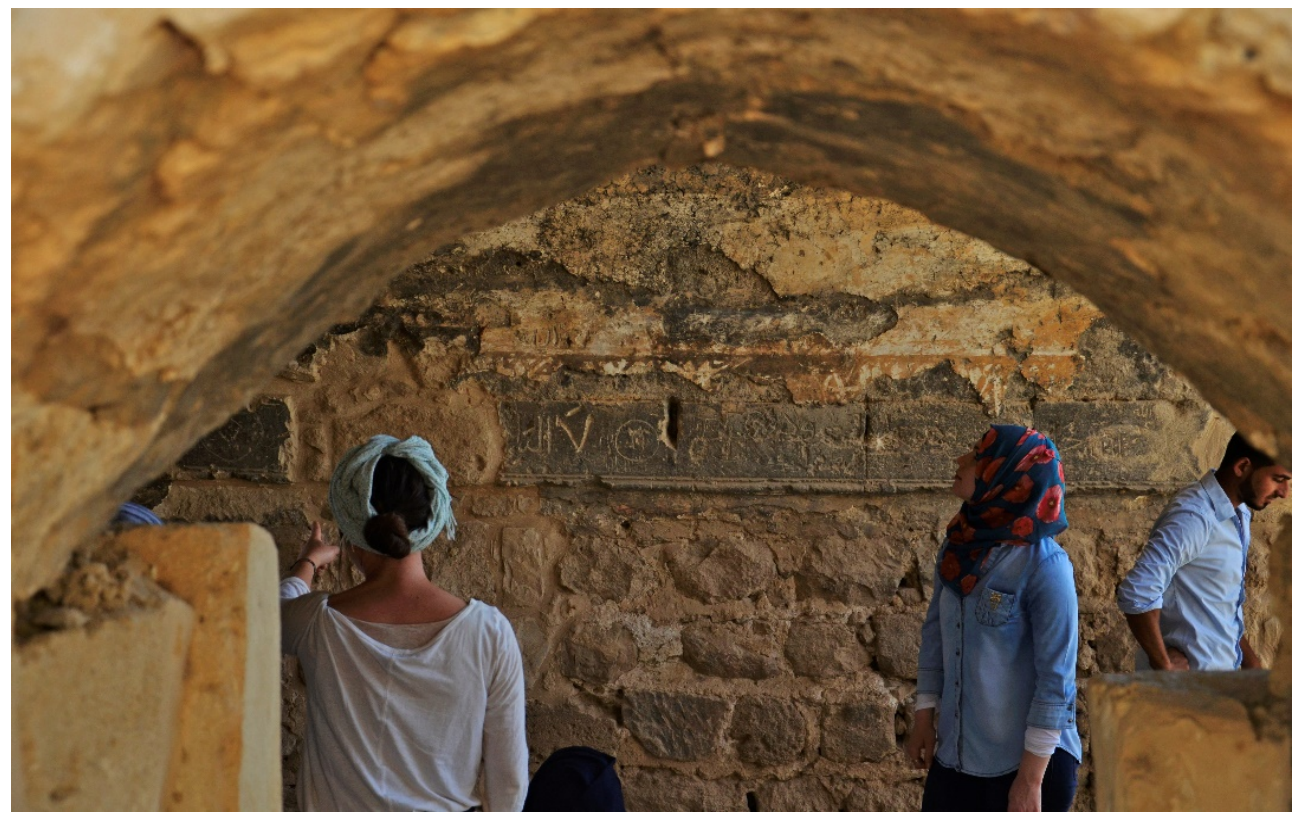

Fig. 4 - Students of the JOAP Guides School visiting Tawaheen es-Sukkar. 


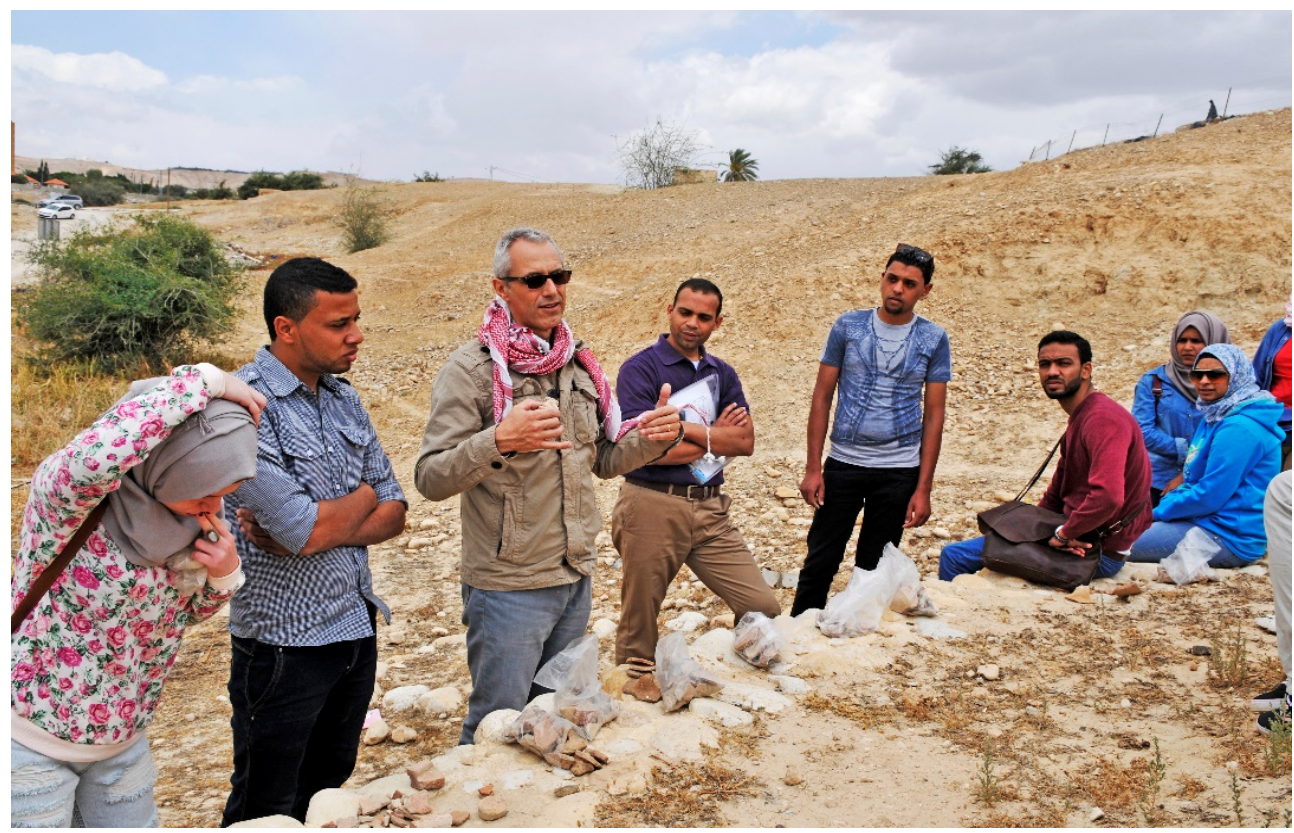

Fig. 5 - Study and classification of Chalcolithic pottery finds in Tell el-Mafjar.

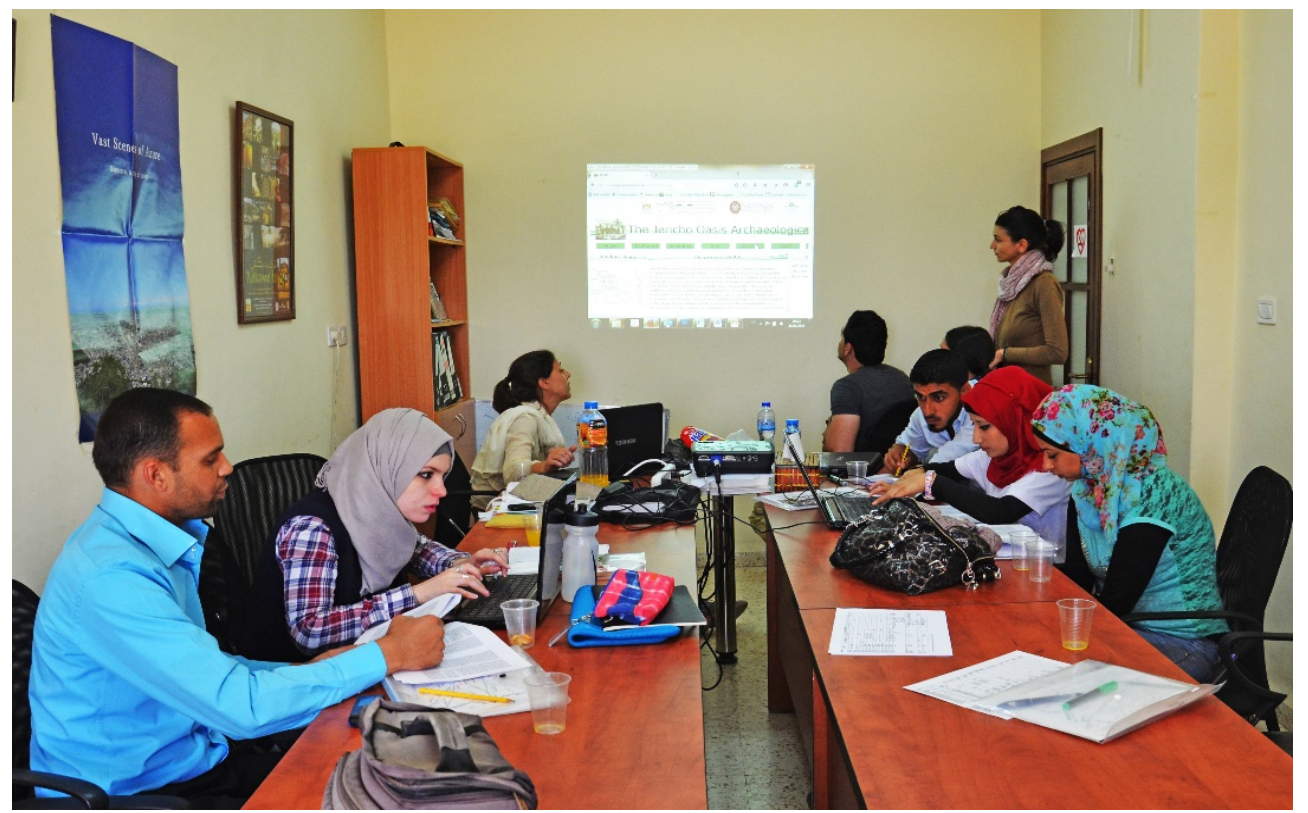

Fig. 6 - Students at work for JOAP panels realization. 


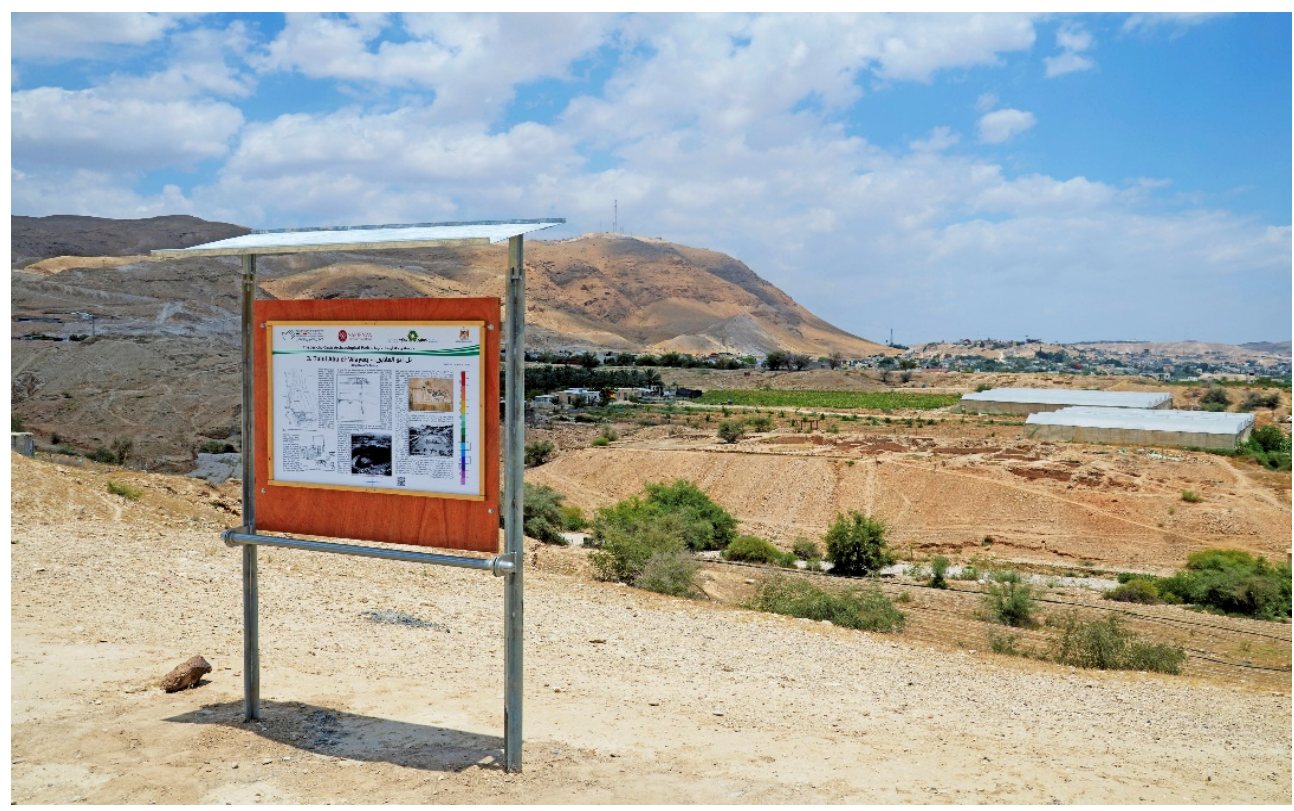

Fig. 7 - The panel at Tulul Abu el-‘Alayiq overlooking King Herod’s palaces.

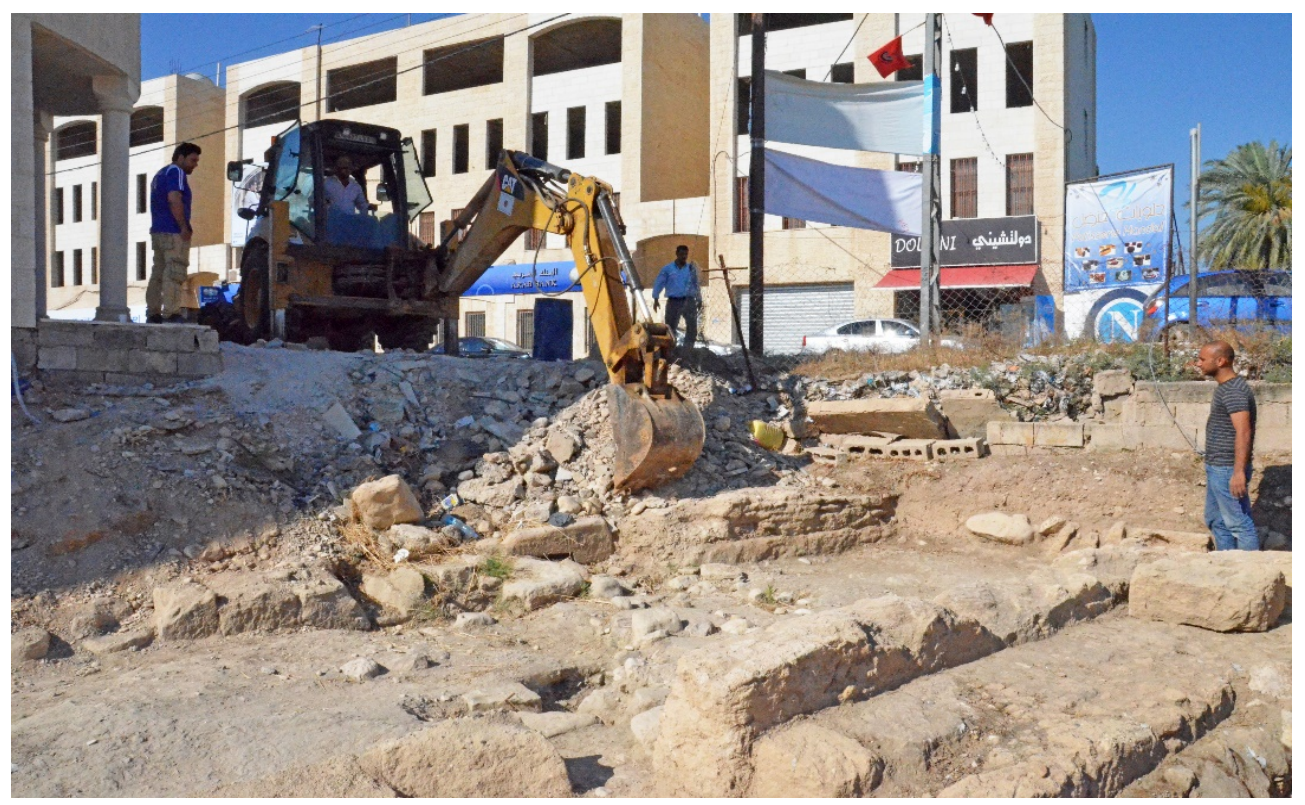

Fig. 8 - Cleaning works at Tell el-Hasan carried out in cooperation with the Ariha Municipality. 


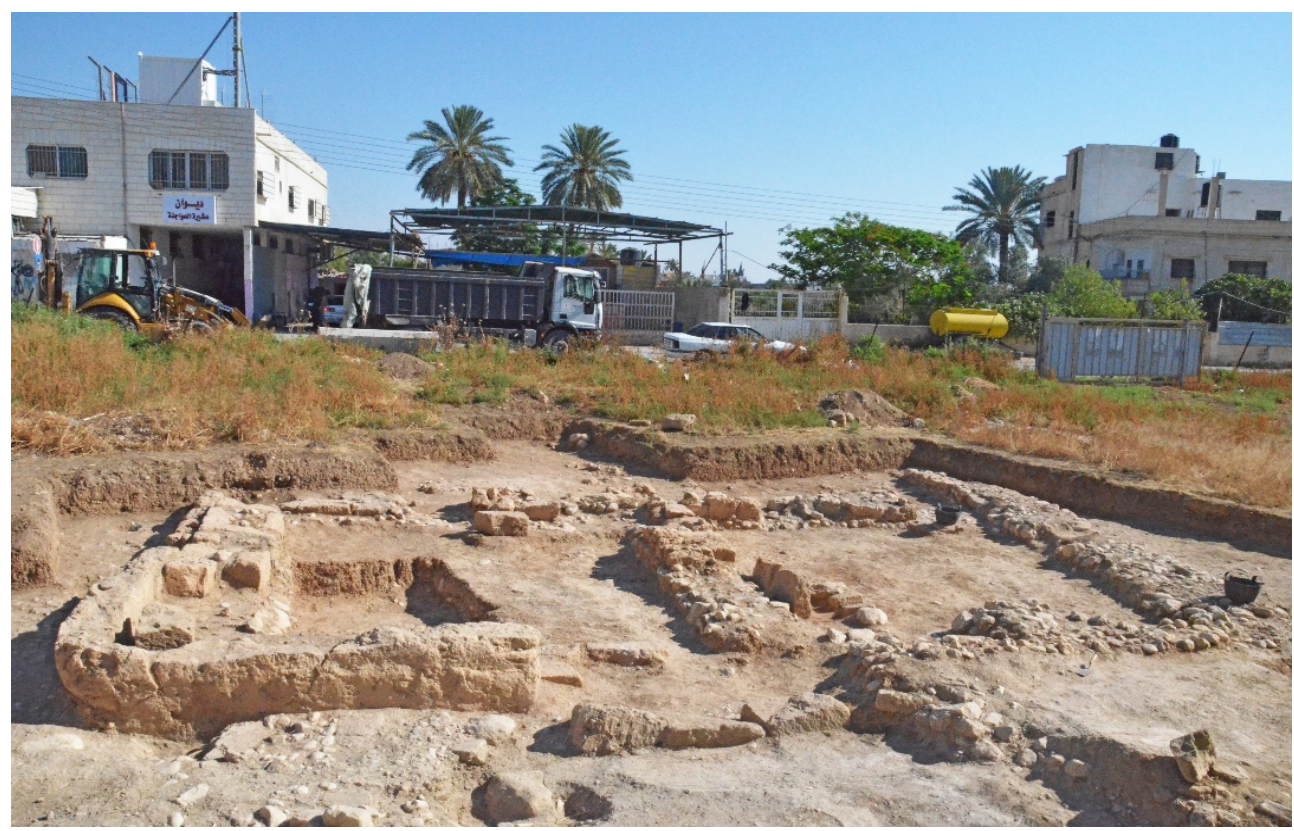

Fig. 9 - Tell el-Hasan, in the Ariha city center, after cleaning and rehabilitation works.

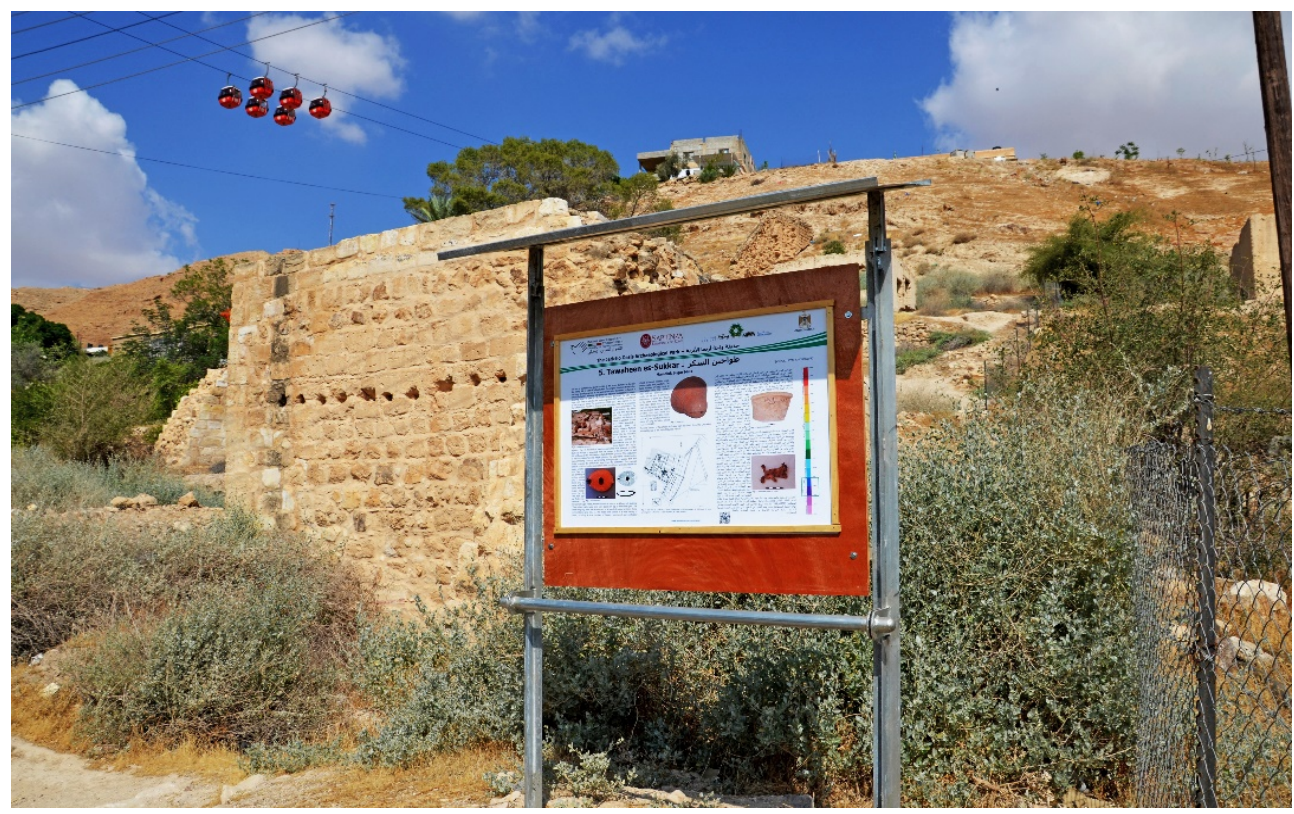

Fig. 10 - The explanatory panel installed in Tawaheen es-Sukkar. 


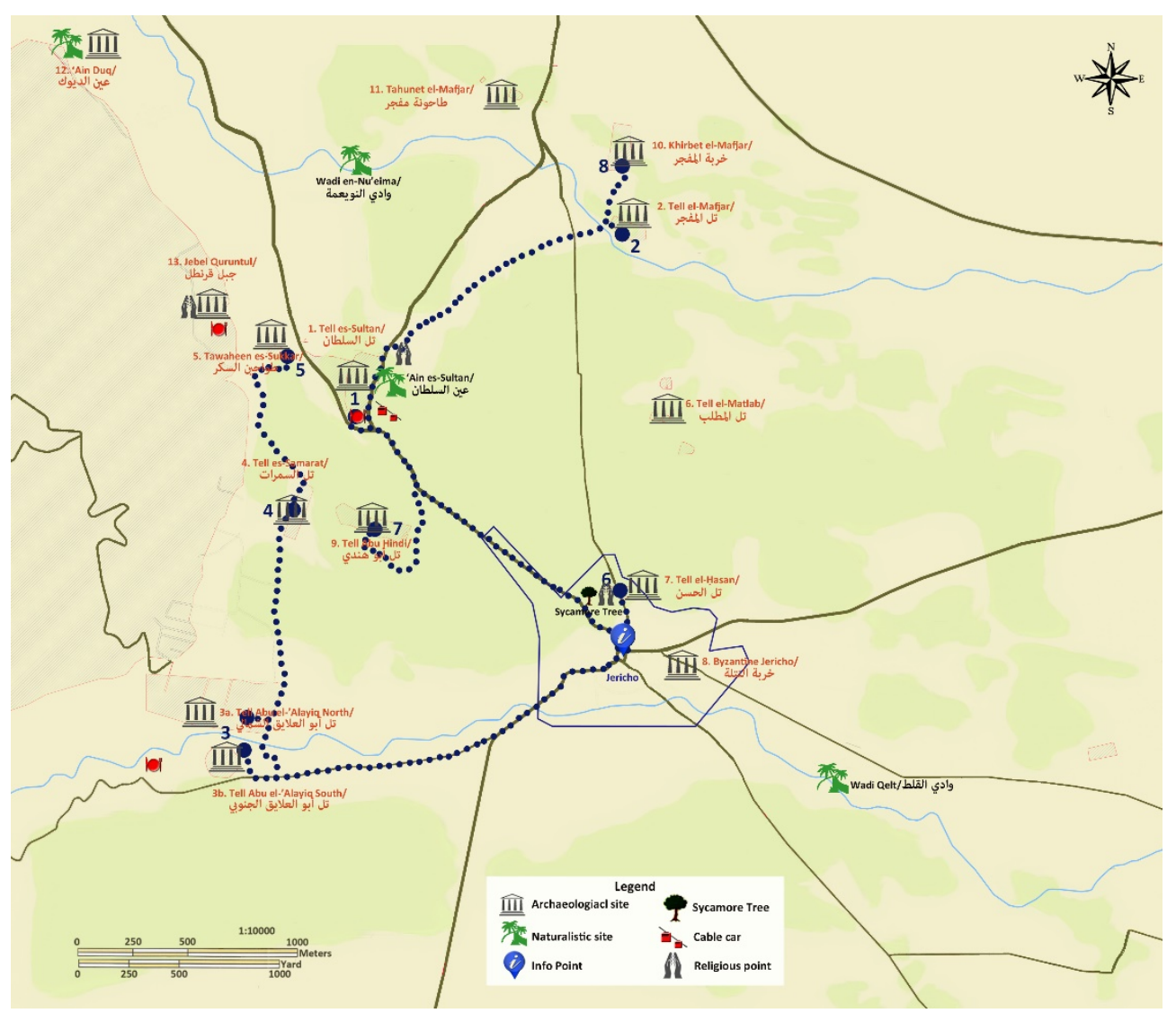

Fig. 11 - Archaeological Itinerary 1: "The Jericho Oasis in history". This includes: 1. Tell es-Sultan (JOAP n. 1); 2. Tell el-Mafjar (JOAP n. 2); 3. Tulul Abu el-'Alayiq (JOAP n. 3); 4. Tell es-Samarat (JOAP n. 4); 5. Tawaheen es-Sukar (JOAP n. 5); 6. Tell el-Hasan (JOAP n. 7); 7. Tell Abu Hindi (JOAP n. 9); 8. Khirbet el-Mafjar (JOAP n. 10). 


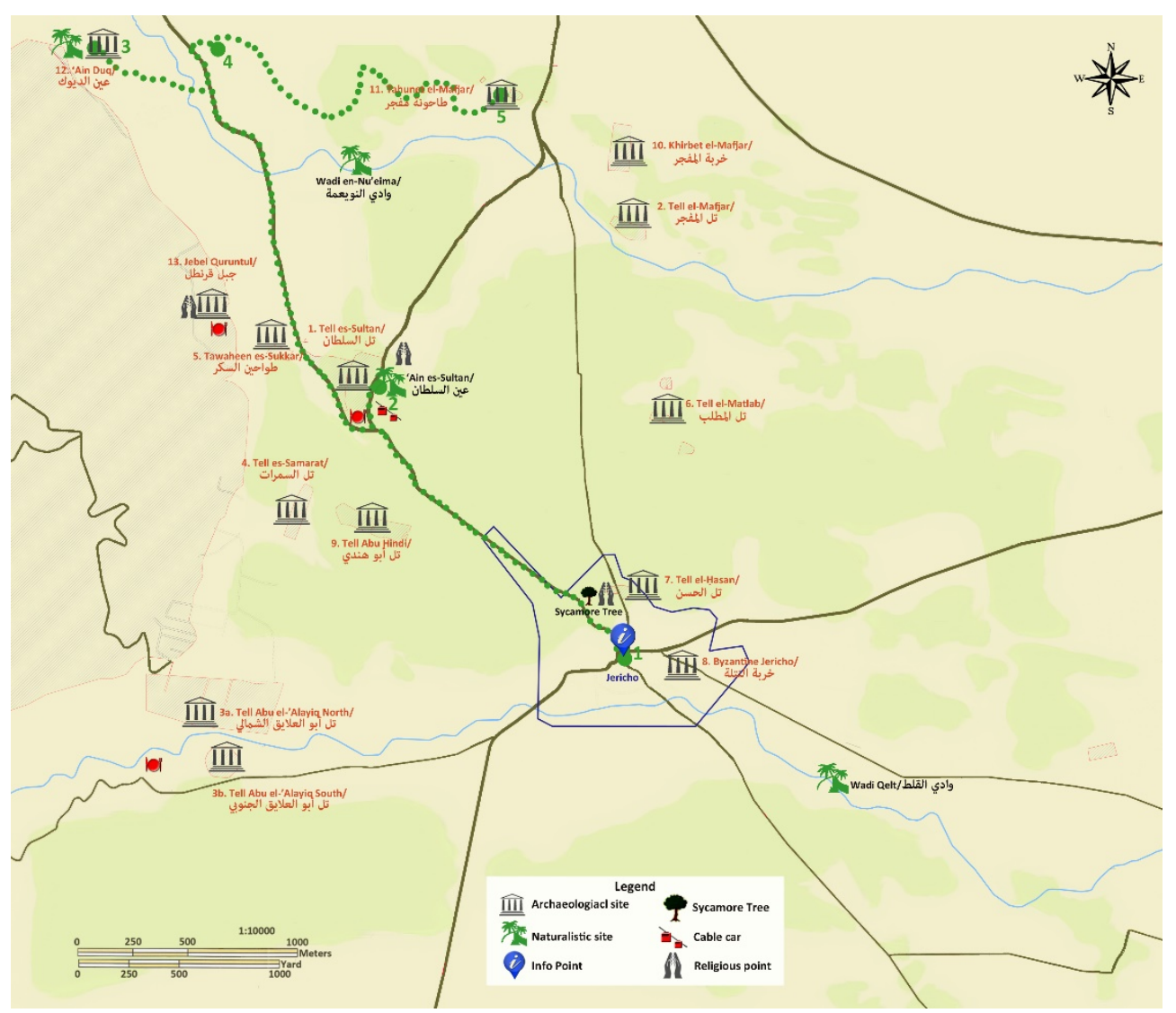

Fig. 12 - Naturalistic Itinerary: “Jericho’s water resources”. This includes: 1. Jericho Oasis Info Point; 2. 'Ain es-Sultan (JOAP n. 12); 3. 'Ain Duq (JOAP n. 12); 4. 'Ain el-Auja (JOAP n. 12); 5. Aqueduct and pool of Khirbet el-Mafjar (JOAP n. 11). 


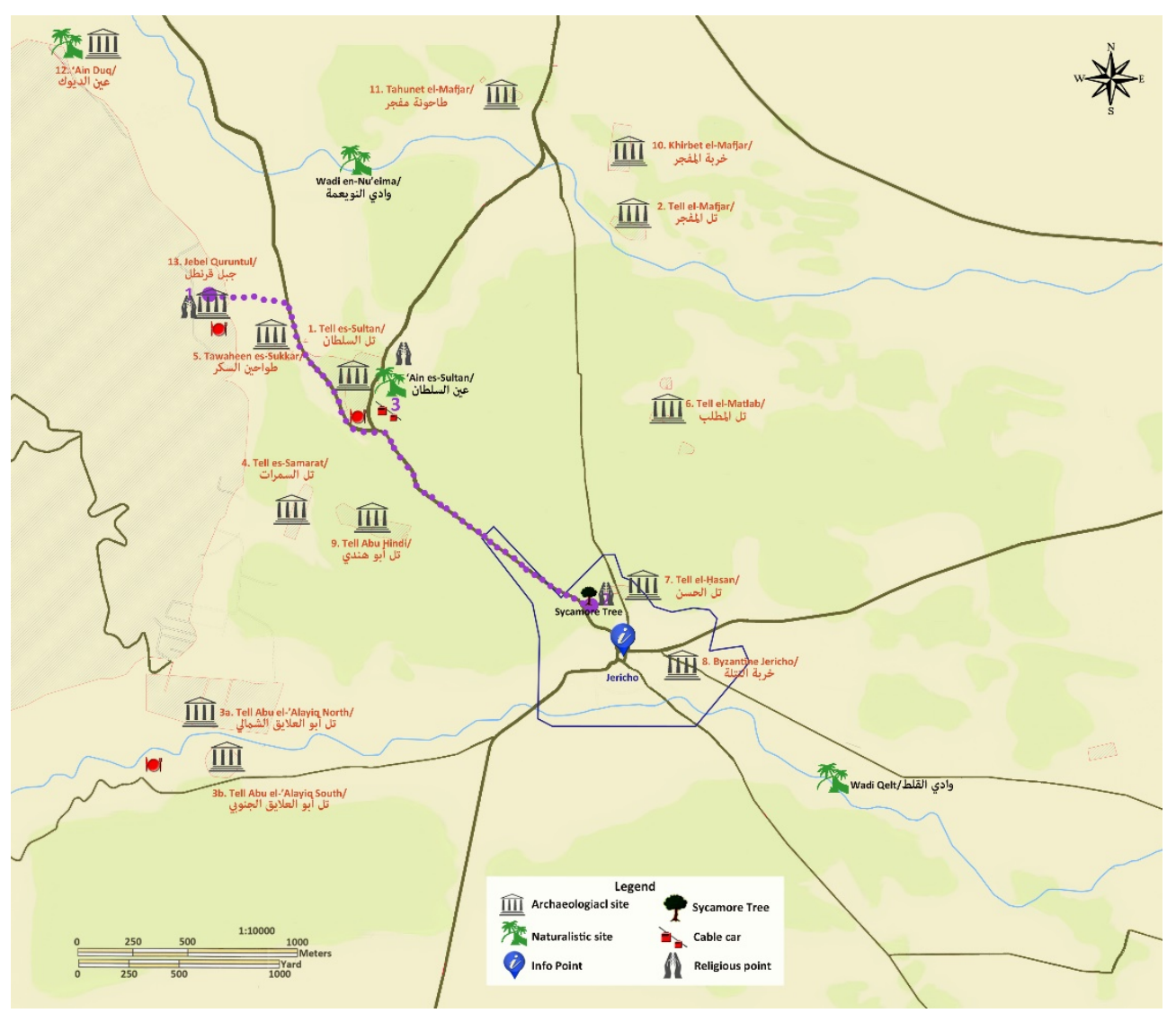

Fig. 13 - Religious Itinerary: "The walk of pilgrims”. This includes: 1. Jebel Quruntul, Mount of Temptations and Monastery of Saint George (JOAP n. 13); 2. Sycamore Tree and the Russian Orthodox Museum; 3. The so-called "Fountain of Prophet Elisha" ('Ain esSultan) and Synagogue of $\mathrm{Na}^{\text {'aran }}$ (JOAP n. 12). 

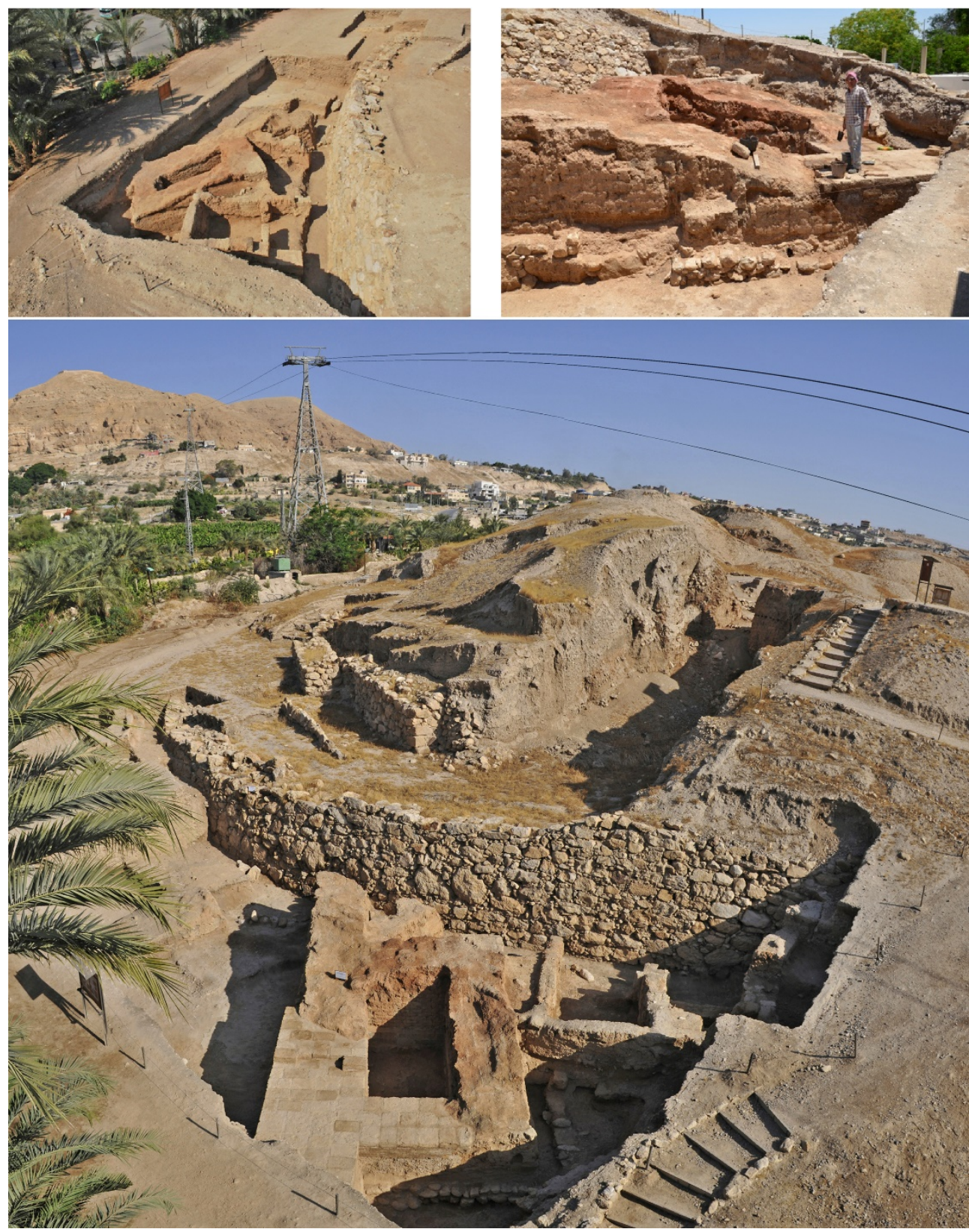

Fig. 14 - Tower A1 before, during and after restoration works. 
Fig. 15 - Making of mud bricks to be used in the restoration of Palace G.
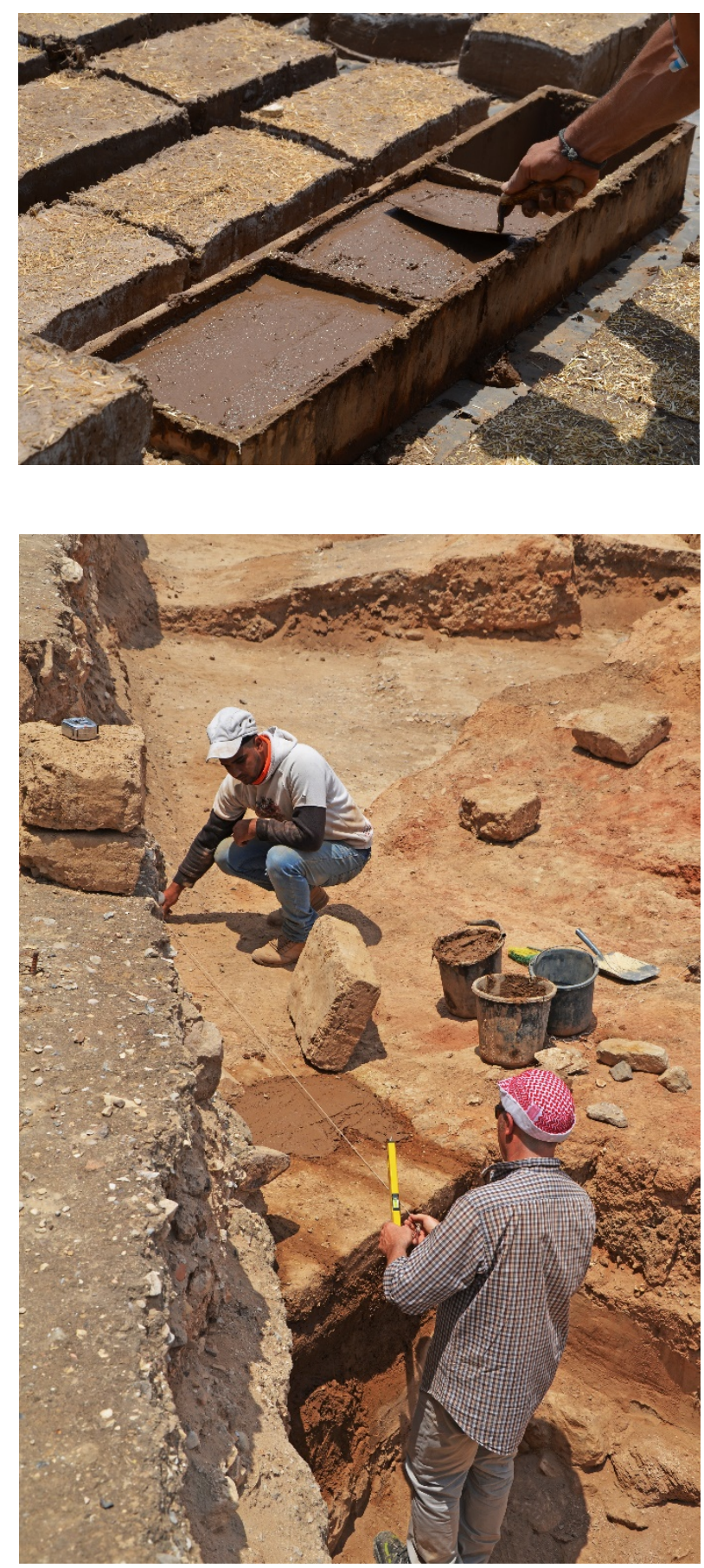

Fig. 16 - Restorers preparing the mortar bed for the sacrifice layer of new bricks. 


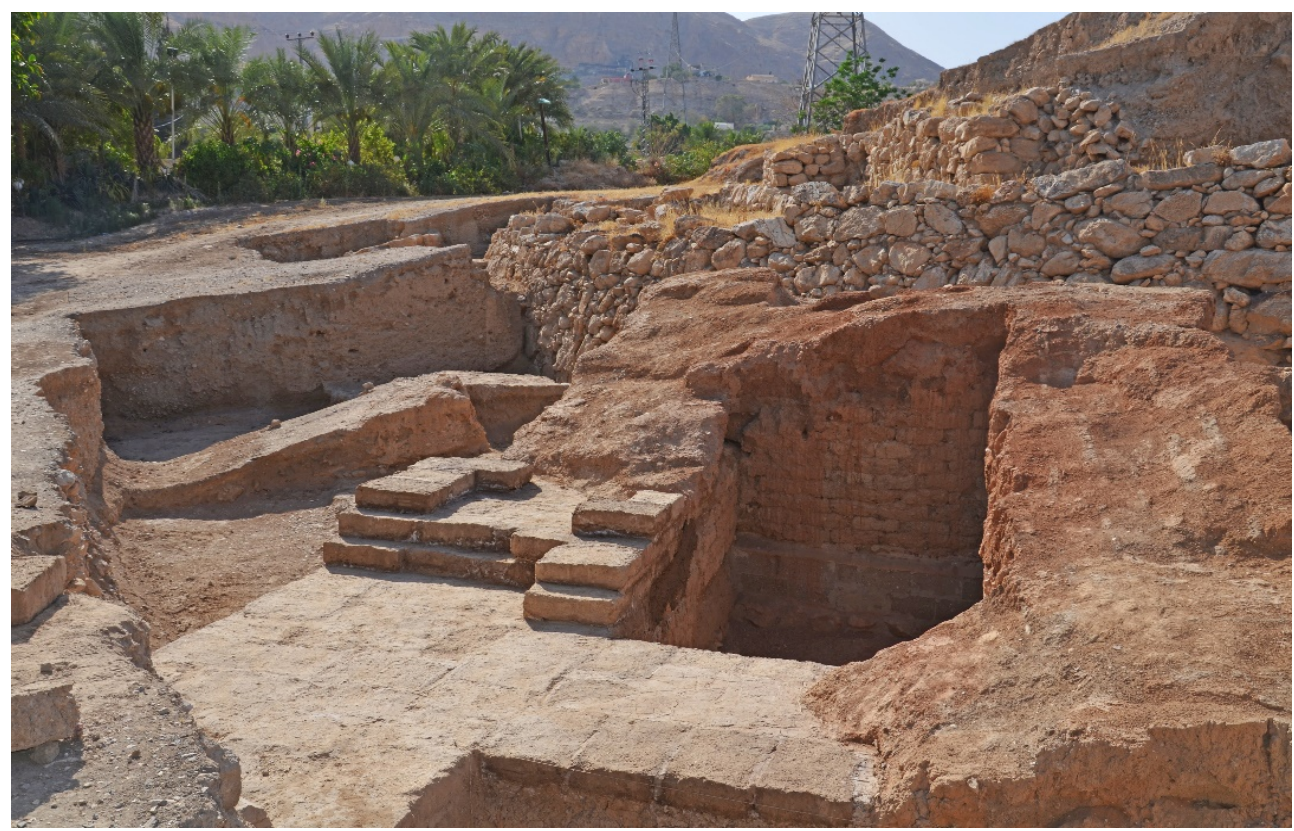

Fig. 17 - Bricks laid on Tower A1.

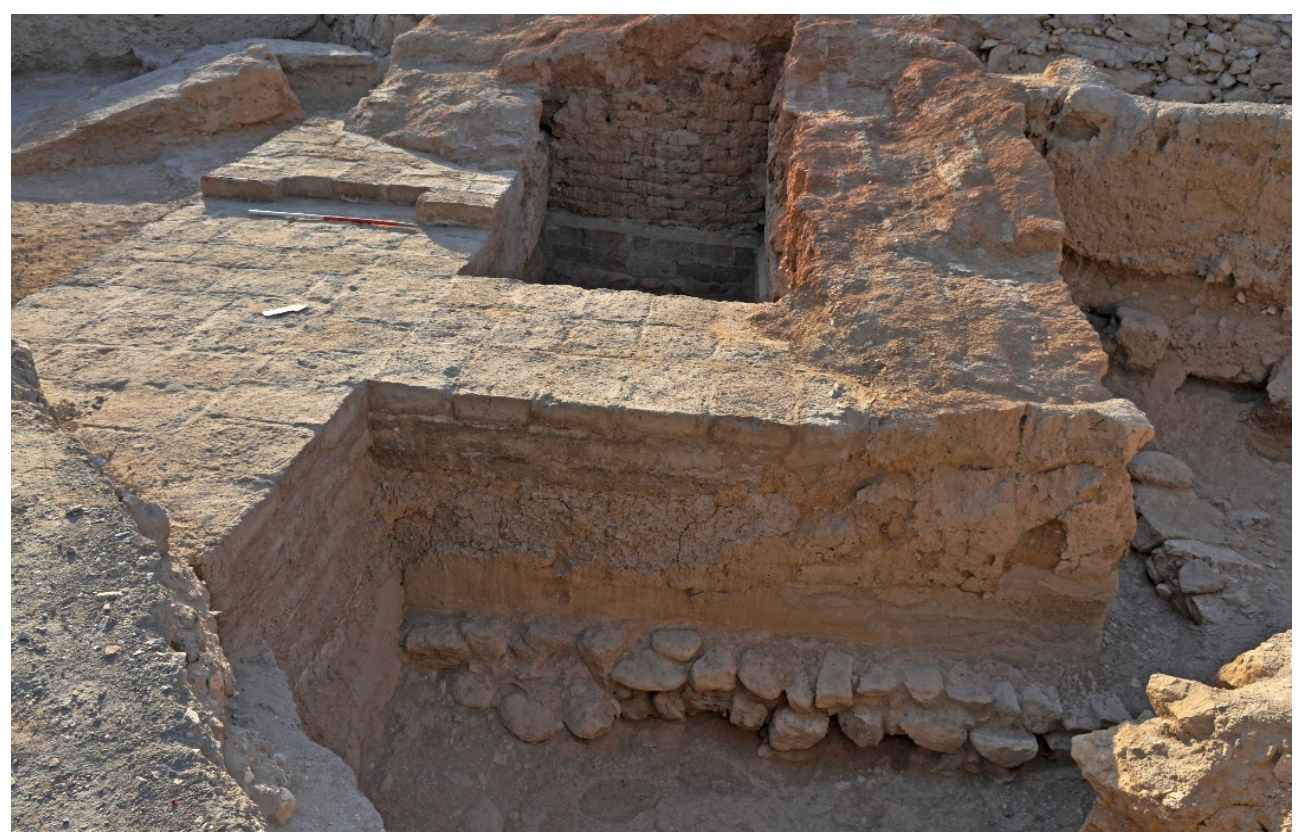

Fig. 18 - The sacrifice revetment layer around the basis of Tower A1. 


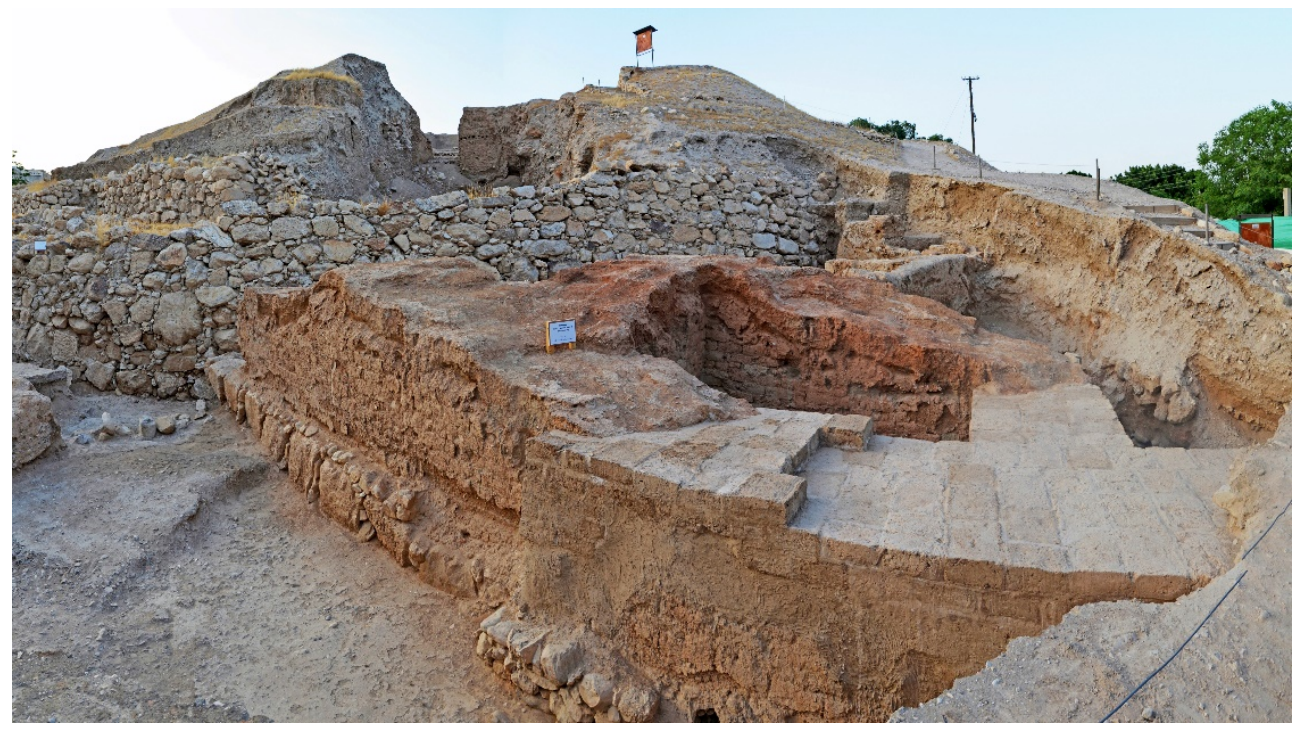

Fig. 19 - Tower A 1 after restoration with new tourist path and a signal giving its name and dating.

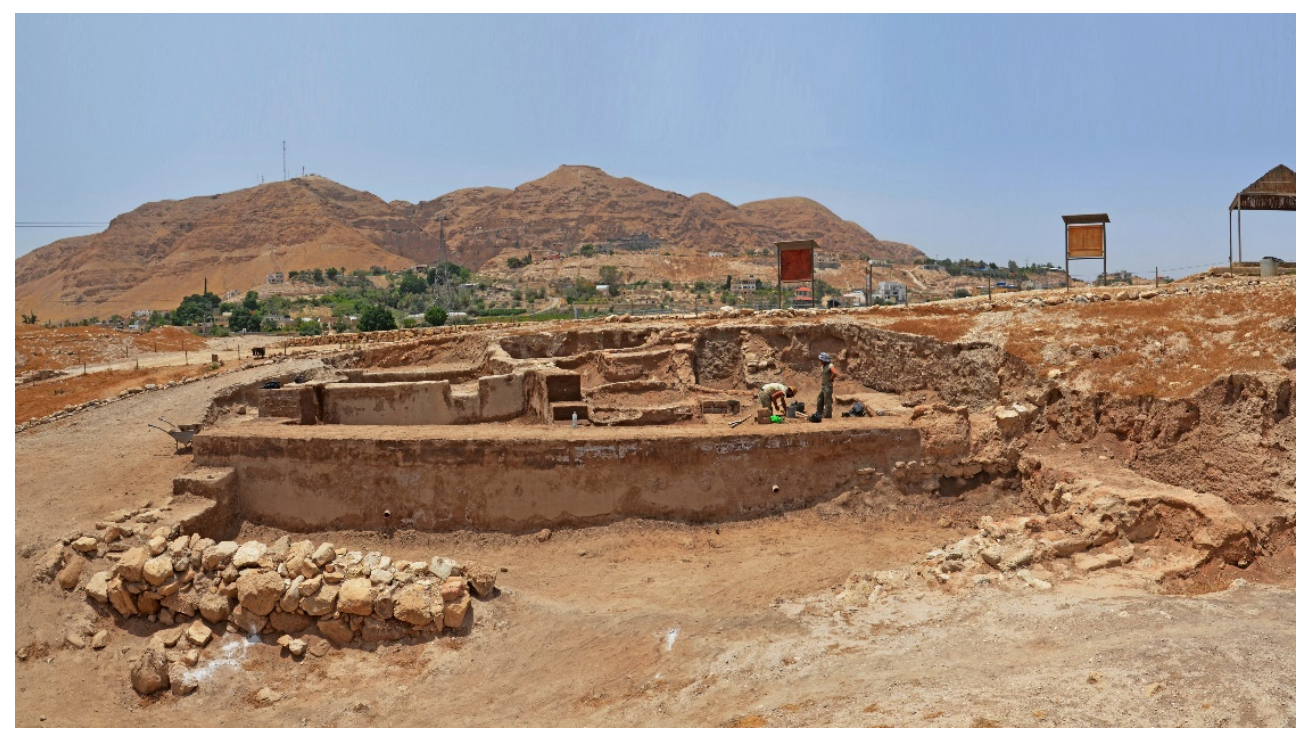

Fig. 20 - General view of Palace G after restoration works. 


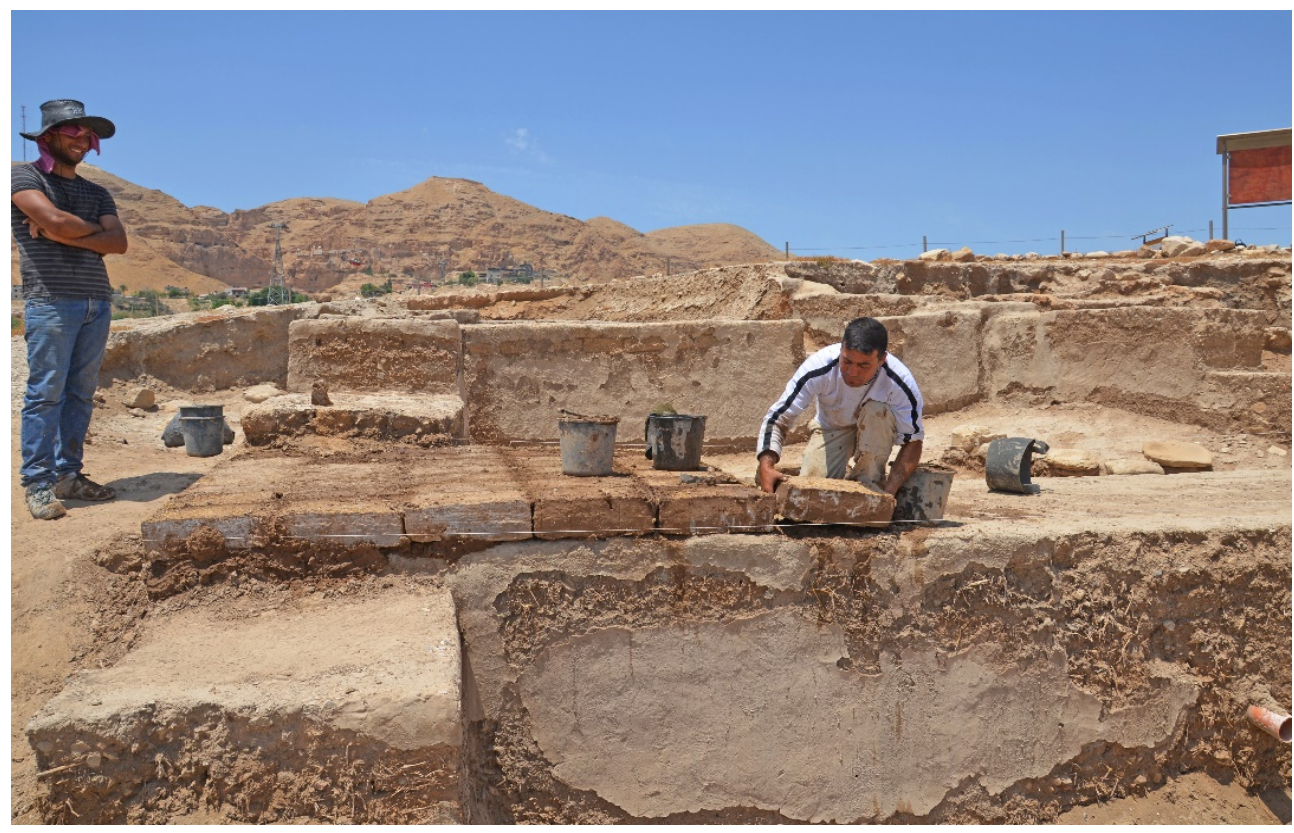

Fig. 21 - Training of a restorer laying bricks on the main wall of Palace G.

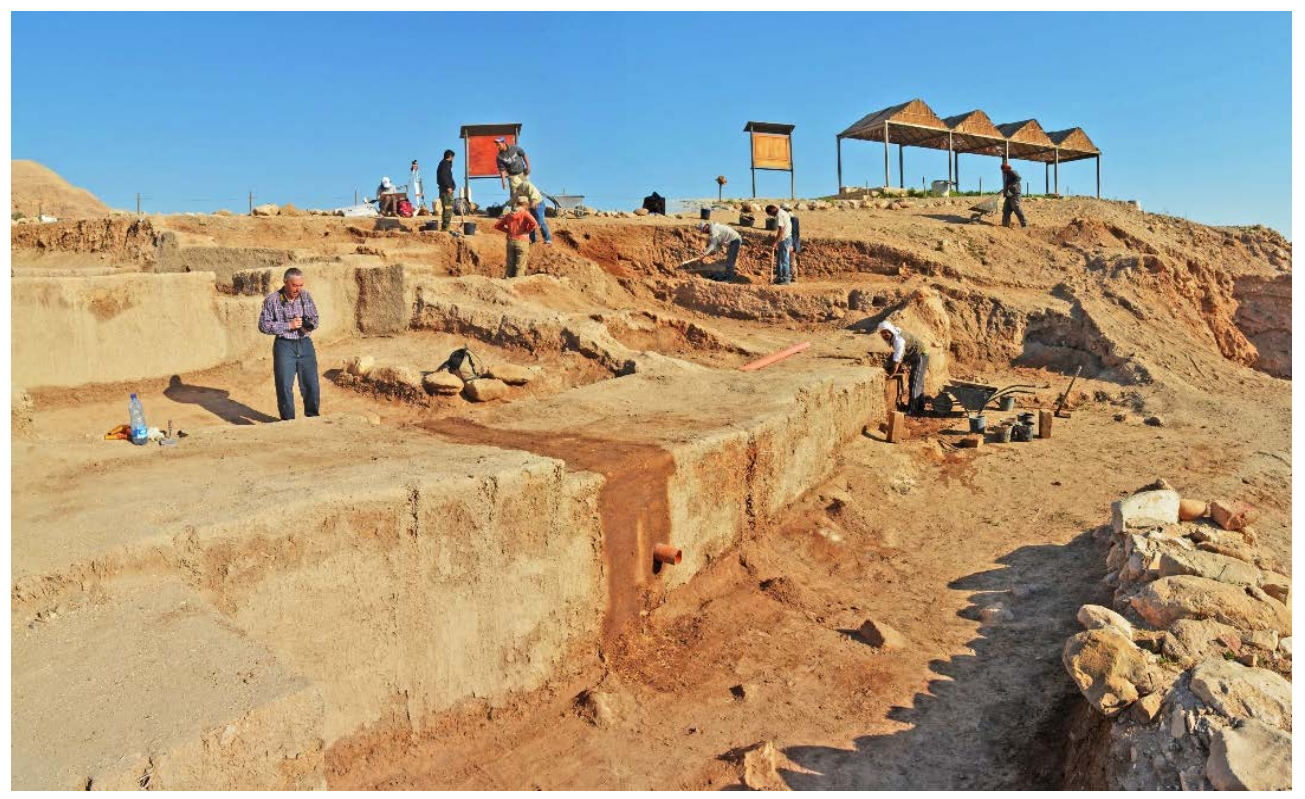

Fig. 22 - Water drainage channel set through Palace G main eastern wall. 


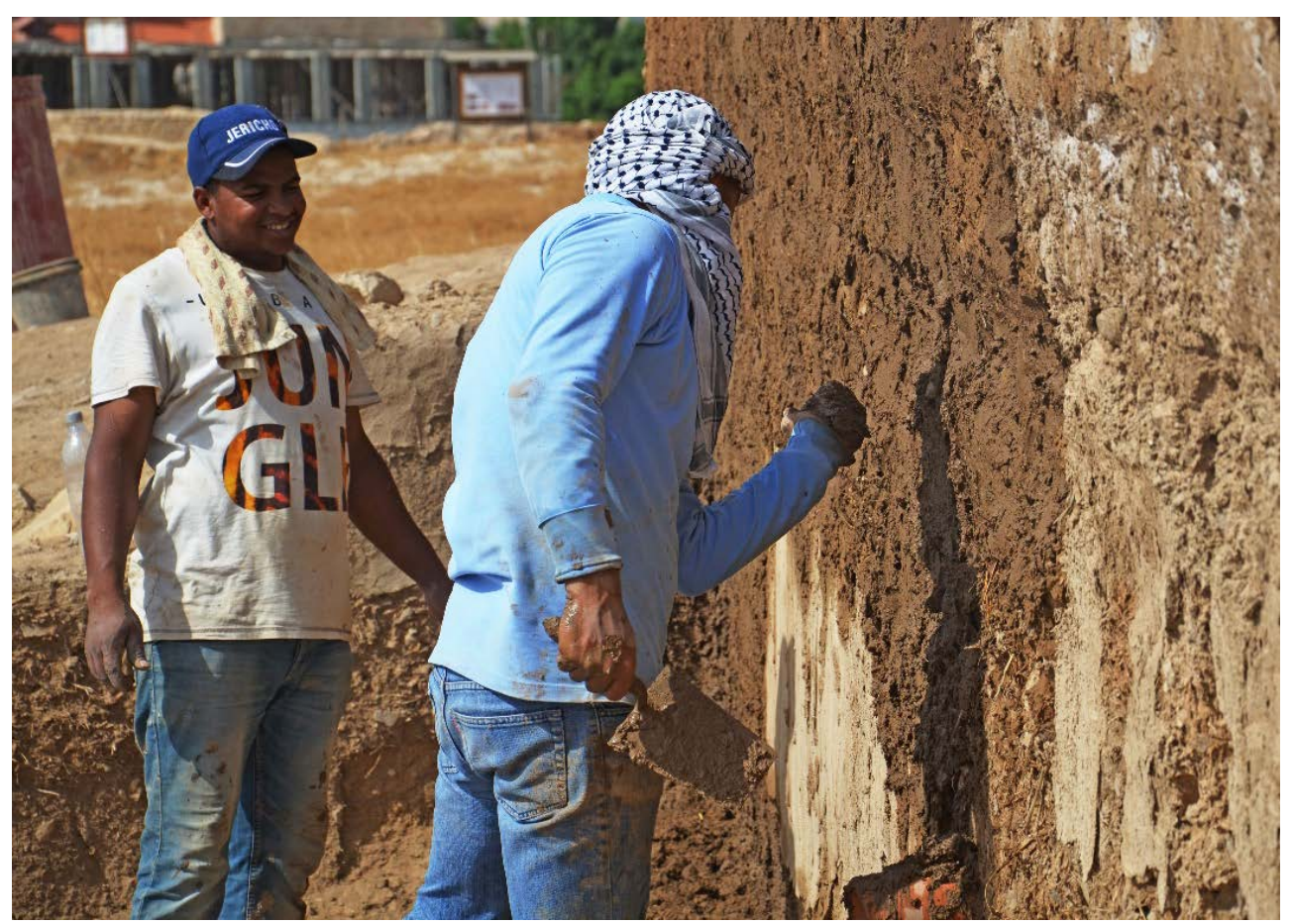

Fig. 23 - Specialized workers coating a mud bricks wall with traditional plaster.

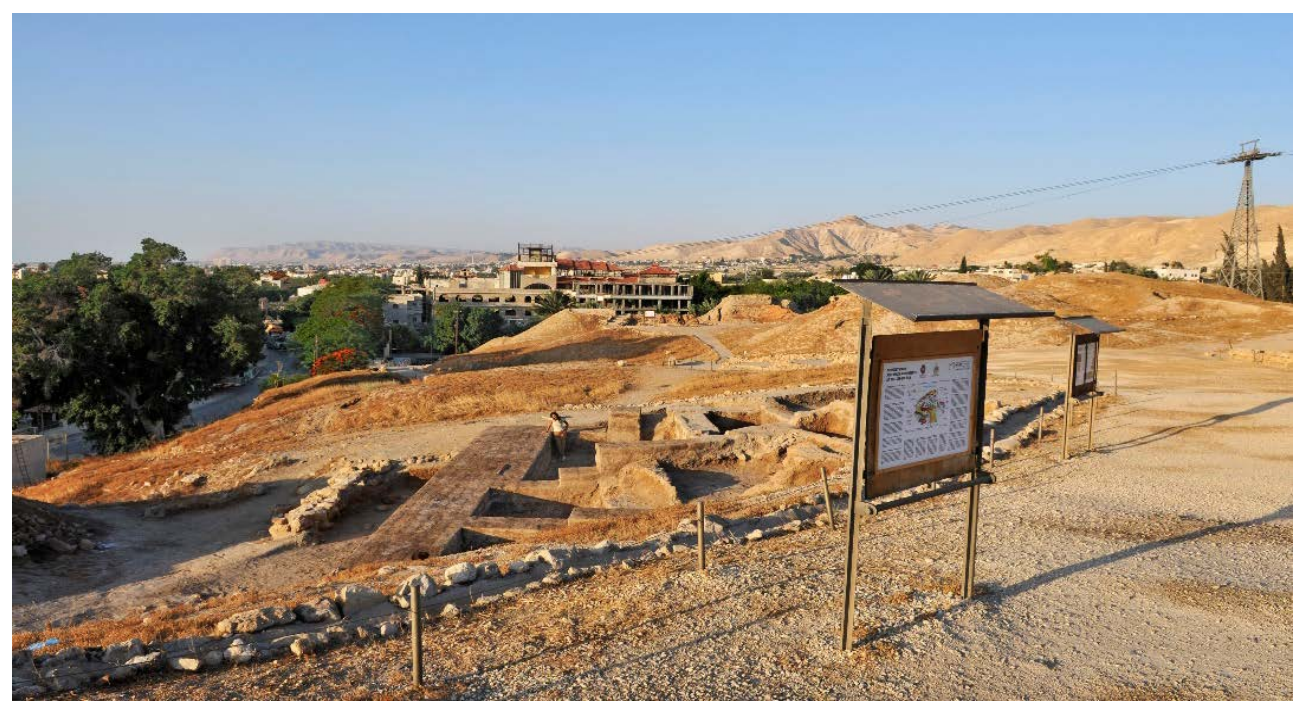

Fig. 24 - Rehabilitated area surrounding Palace G. 


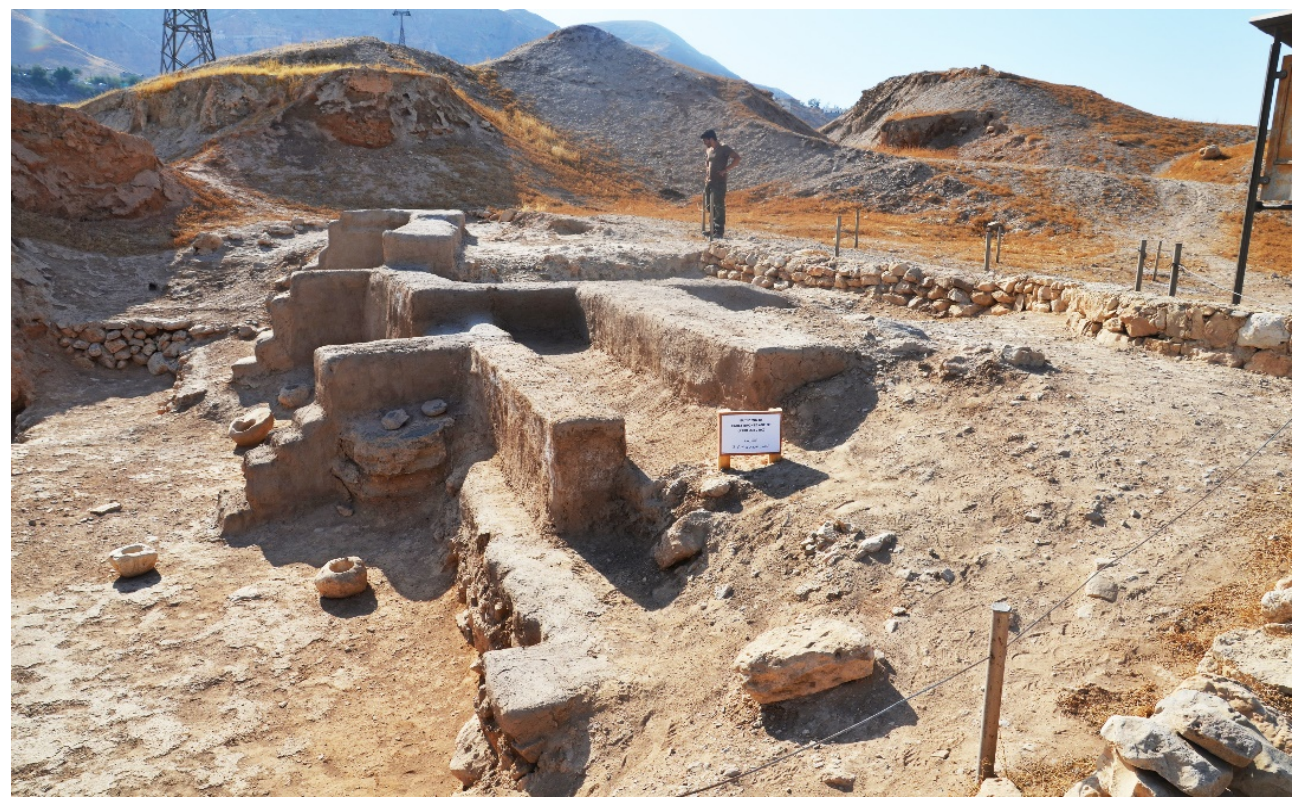

Fig. 25 - General view of Building B1 after rehabilitation with signal indicating name and dating of the monument.

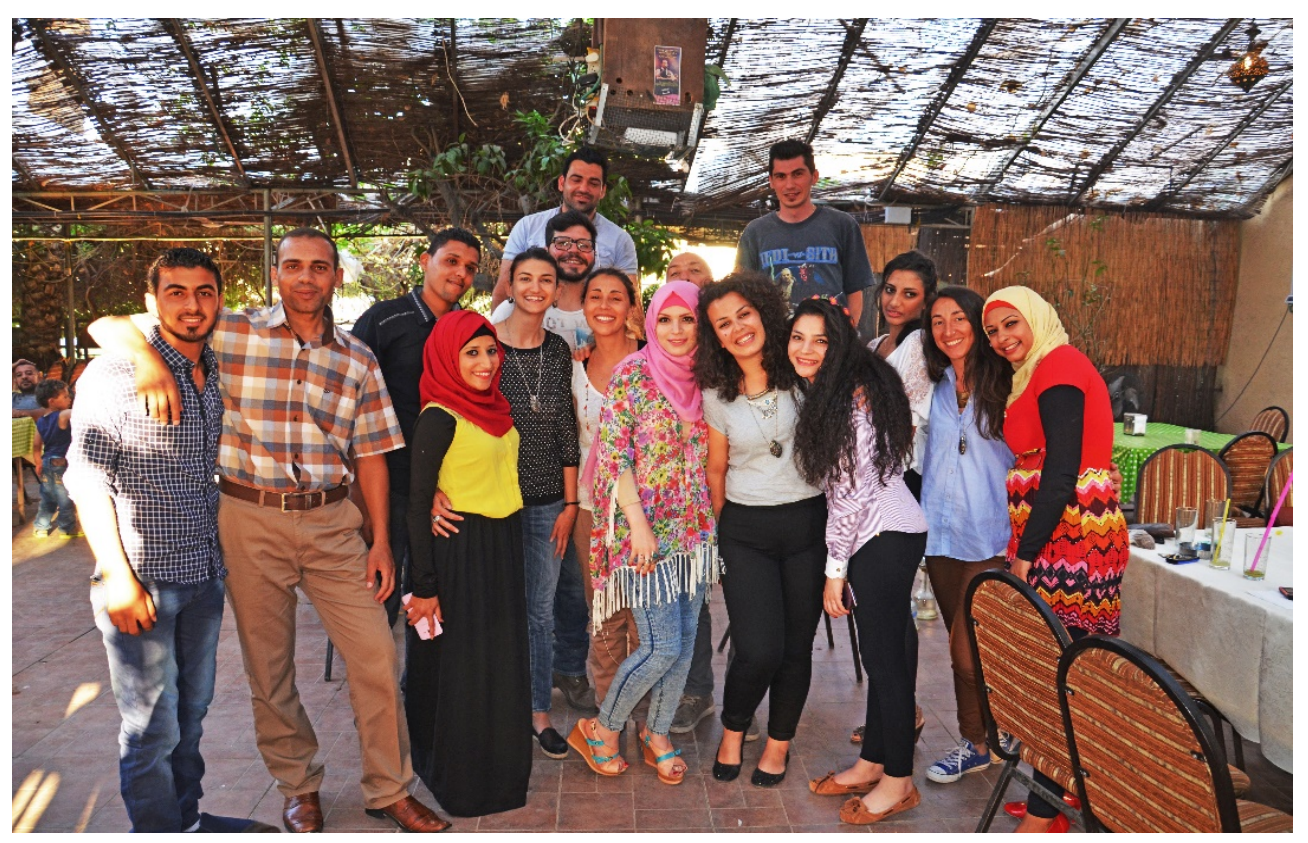

Fig. 26 - Students trained as tourist guides in the last day of the JOAP Guides School. 


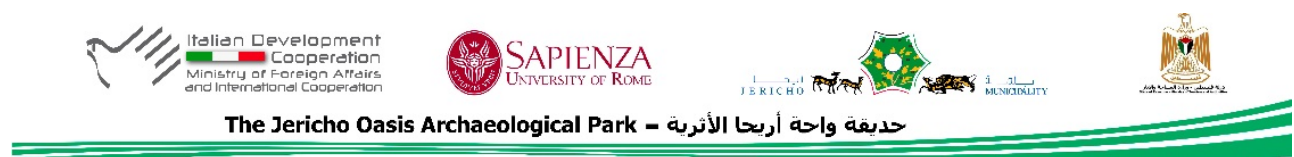

\section{Tawaheen es-Sukkar - طواحين السكر - حدابها -}
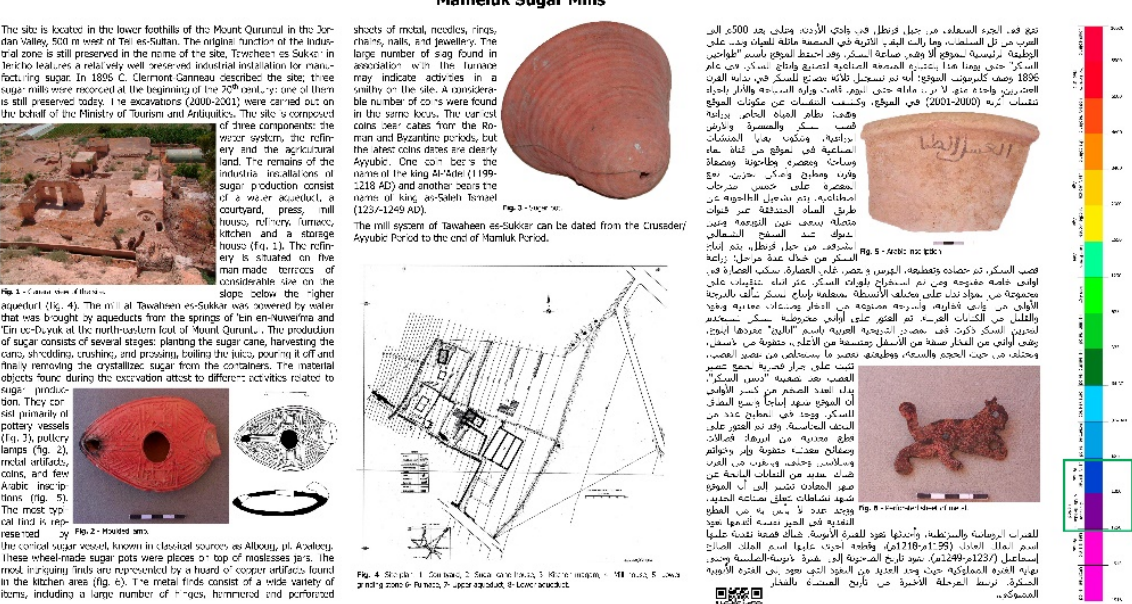

暍祖

Fig. 27 - A panel with English and Arabic texts illustrating a site and its monuments.

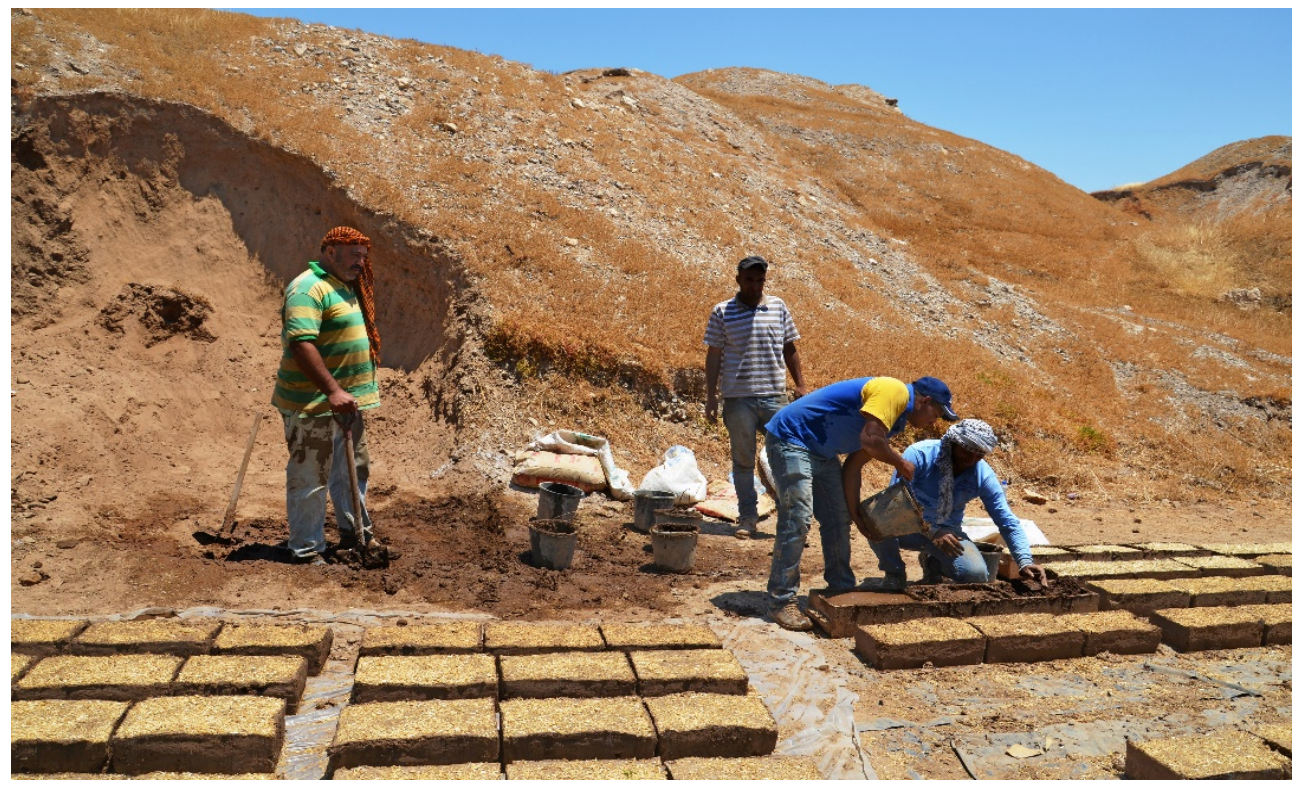

Fig. 28 - Mud brick architecture restorers during training. 


\section{SOMMARIO}

DipartimENTo SCIENZE DELl'ANTICHITÀ

SEZIONE di ORIENTALISTICA

\section{VICINO ORIENTE \\ XIX - 2015}

L. Nigro - Bethlehem in the Bronze and lron Ages
in the light of recent discoveries by the Palestinian MOTA-DACH

$\checkmark$. Pisaniello - Parallel passages among Hittite-Luwian rituals:

for the restoration of $K U B 35.146$

F. Spagnoli - Una testa di sileno in bronzo da Mozia

N. Chiaren

dall Area sacra del Kothon a Mozia

G. Labisi - al-Fudayn: an Umayyad residence in Northern Jordan

P. Buzi - Early Christianity in the Fayyūm: the new contribution of archaeology

I. Materia - Preliminary notes on the ware depicted on the ceiling

of the Cappella Palatina in Palermo

S. Autiero - Indian Ocean trade:

a reassessment of the pottery find
$\left(3^{\text {rd }}\right.$ century $B C-S^{S^{t h}}$ century $\left.A D\right)$

M.M. Jamhawi - N. Al-Shakarchi - I. Al-Hashimi

Assessment of tourists' satisfaction in the downtown of Amman

SCAVI E RICERCHE

L. Nigro - C. Fiaccavento - M. Jaradat - J. Yasine

A

L. Nigro - D. Montanari - M. Ghayyada - J. Yasine

A Middle Bronze and Iron Age necropolis near Bethlehem (Palestine)

L. Nigro - G. Ripepi - I. Hamdan - J. Yasine

15 Interim Report

and valorization of archaeological heritage

R. Francia - L'archivio di tavolette del complesso B-C-H di Büyükkale

organizazione degli archivi reali ittiti. Considerazioni preliminari

V. Pisaniello - La collezione di tavolette del complesso B-C-H di Büyükkale

T. De Vincenzi - L'archivio di tavolette del complesso B-C-H
sull'acropoli di Büyükkale

Museo del Vicino Oriente, Egitto e Mediterraneo

L. Nigro - Il nuovo allestimento del Museo del Vicino Oriente,

Egitto e Mediterraneo della Sapienza

D. Montanari - Bollettino delle attività del Museo del Vicino Oriente,

Egito e Meditraneo della Sapienza, anno 2015

RECENSIONI

A. Orsingher - E. PAPPA (2013), Early Iron Age Exchange in the West:

(Ancient Near Eastern Studies Supplement Series 43)

Leuven - Paris - Walpole 2013, MA.: Peeters $\frac{1}{2}$

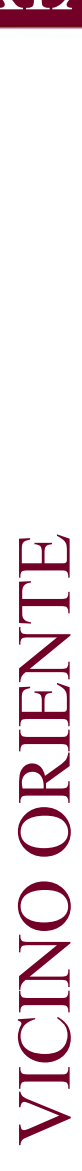

345

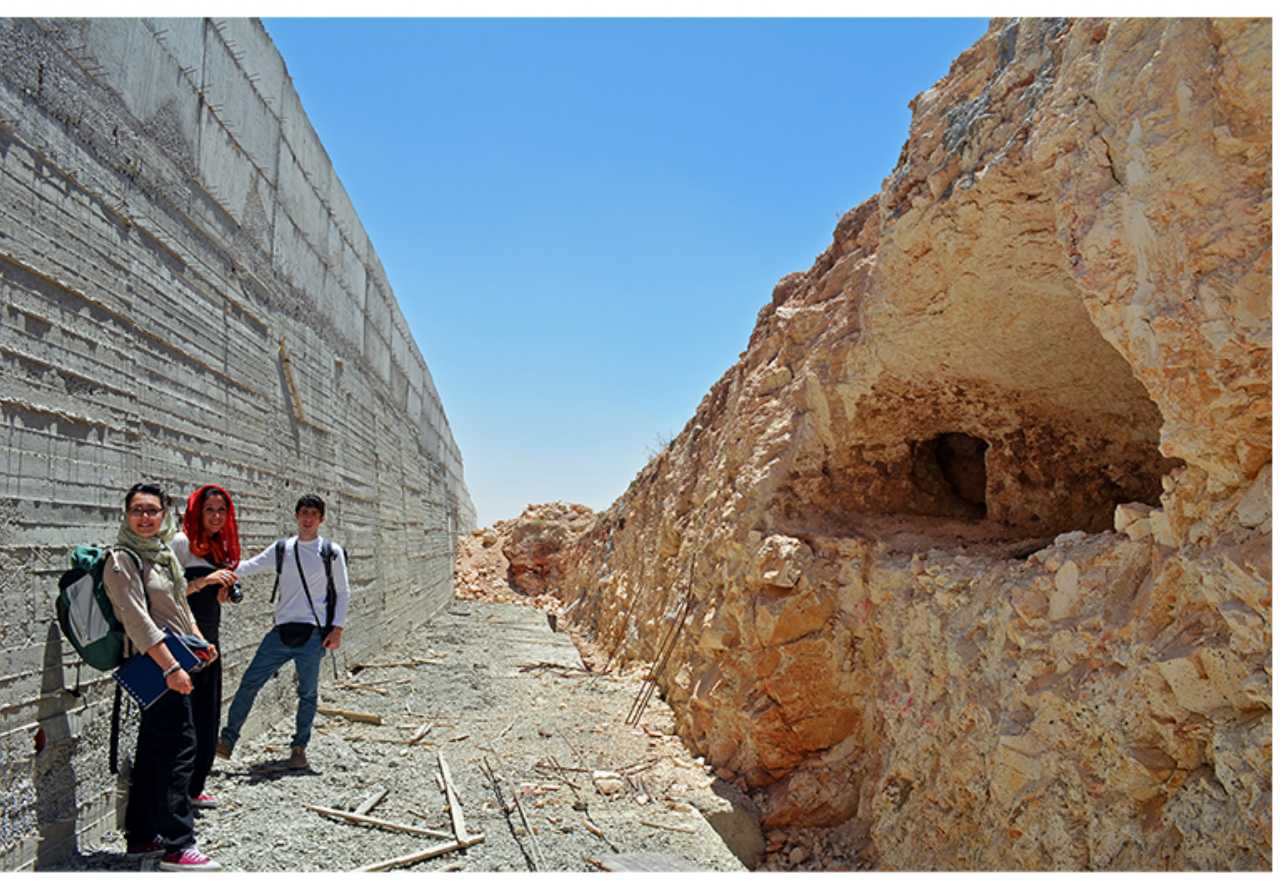

ROMA 2015 


\section{VICINO ORIENTE XIX - 2015}


VICINO ORIENTE

SAPIENZA UNIVERSITÀ DI ROMA

DIPARTIMENTO SCIENZE DELL'ANTICHITÀ

SEZIONE DI ORIENTALISTICA

Scientific Editor: Lorenzo Nigro

International Scientific Committee: Brian Rose, Frank Braemer, Mounir Fantar, Piero Bartoloni, Thomas Schaefer, Zeidan Kafafi

National Scientific Committee: Carlo Giovanni Cereti, Maria Vittoria Fontana, Sebastiano Tusa, Massimiliano Marazzi

Editorial Board: Daria Montanari, Chiara Fiaccavento

Tipografia: SK7 - Roma

ISSN 0393-0300

Rivista con comitato di referee

Journal with international referee system

www.lasapienzatojericho.it/SitoRivista/Journal/Rivista.php

In copertina: Tomba B9, necropoli di Khalet al-Jam’a (Betlemme). 
VICINO ORIENTE

SAPIENZA UNIVERSITÀ DI ROMA

DIPARTIMENTO SCIENZE DELL'ANTICHITÀ

SEZIONE DI ORIENTALISTICA

\section{SOMMARIO}

ARTICOLI

L. Nigro - Bethlehem in the Bronze and Iron Ages

in the light of recent discoveries by the Palestinian MOTA-DACH

V. Pisaniello - Parallel passages among Hittite-Luwian rituals:

for the restoration of KUB 35.146

F. Spagnoli - Una testa di sileno in bronzo da Mozia

N. Chiarenza - Una matrice per terrecotte con sileno dall'Area sacra del Kothon a Mozia

G. Labisi - al-Fudayn: an Umayyad residence in Northern Jordan

P. Buzi - Early Christianity in the Fayyūm: the new contribution of archaeology

I. Materia - Preliminary notes on the ware depicted on the ceiling

of the Cappella Palatina in Palermo

S. Autiero - Indian Ocean trade:

a reassessment of the pottery finds from a multidisciplinary point of view ( $3^{\text {rd }}$ century $B C-5^{\text {th }}$ century $\left.A D\right)$

M.M. Jamhawi - N. Al-Shakarchi - I. Al-Hashimi

Assessment of tourists' satisfaction in the downtown of Amman

SCAVI E RICERCHE

L. Nigro - C. Fiaccavento - M. Jaradat - J. Yasine Archaeology from A to Z: Abu Zarad, an ancient town in the heartland of Palestine

L. Nigro - D. Montanari - M. Ghayyada - J. Yasine

Khalet al-Jam'a. A Middle Bronze and Iron Age necropolis near Bethlehem (Palestine) 185 
VICINO ORIENTE

SAPIENZA UNIVERSITÀ DI ROMA

DIPARTIMENTO SCIENZE DELL'ANTICHITÀ

SEZIONE DI ORIENTALISTICA

L. Nigro - G. Ripepi - I. Hamdan - J. Yasine

The Jericho Oasis Archaeological Park - 2015 Interim Report.

Italian-Palestinian Cooperation for protection

and valorization of archaeological heritage

R. Francia - L'archivio di tavolette del complesso B-C-H di Büyükkale

e l'organizzazione degli archivi reali ittiti. Considerazioni preliminari

V. Pisaniello - La collezione di tavolette del complesso B-C-H di Büyükkale

T. De Vincenzi - L'archivio di tavolette del complesso B-C-H sull'acropoli di Büyükkale

Museo del Vicino ORIente, Egitto e MediterRaneo

L. Nigro - Il nuovo allestimento del Museo del Vicino Oriente,

Egitto e Mediterraneo della Sapienza

D. Montanari - Bollettino delle attività del Museo del Vicino Oriente,

Egitto e Mediterraneo della Sapienza, anno 2015

\section{RECENSIONI}

A. Orsingher - E. PAPPA (2013), Early Iron Age Exchange in the West:

Phoenicians in the Mediterranean and the Atlantic

(Ancient Near Eastern Studies Supplement Series 43),

Leuven - Paris - Walpole 2013, MA.: Peeters 